\title{
WRF-Chem simulation of aerosol seasonal variability in the San Joaquin Valley
}

\author{
Longtao Wu ${ }^{1}$, Hui Su${ }^{1}$, Olga V. Kalashnikova ${ }^{1}$, Jonathan H. Jiang ${ }^{1}$, Chun Zhao ${ }^{2}$, Michael J. Garay ${ }^{1}$, \\ James R. Campbell ${ }^{3}$, and Nanpeng $\mathbf{Y u}^{4}$ \\ ${ }^{1}$ Jet Propulsion Laboratory, California Institute of Technology, Pasadena, CA, USA \\ ${ }^{2}$ School of Earth and Space Sciences, University of Science and Technology of China, Hefei, Anhui, China \\ ${ }^{3}$ Naval Research Laboratory, Monterey, CA, USA \\ ${ }^{4}$ University of California, Riverside, Riverside, CA, USA \\ Correspondence to: Longtao Wu (longtao.wu@jpl.nasa.gov)
}

Received: 4 November 2016 - Discussion started: 29 November 2016

Revised: 20 April 2017 - Accepted: 7 May 2017 - Published: 17 June 2017

\begin{abstract}
WRF-Chem simulations of aerosol seasonal variability in the San Joaquin Valley (SJV), California, are evaluated by satellite and in situ observations. Results show that the WRF-Chem model successfully captures the distribution and magnitude of and variation in SJV aerosols during the cold season. However, aerosols are not well represented in the warm season. Aerosol simulations in urban areas during the cold season are sensitive to model horizontal resolution, with better simulations at $4 \mathrm{~km}$ resolution than at $20 \mathrm{~km}$ resolution, mainly due to inhomogeneous distribution of anthropogenic emissions and precipitation that is represented better in the $4 \mathrm{~km}$ simulation. In rural areas, the model sensitivity to grid size is rather small. Our observational analysis reveals that dust is a primary contributor to aerosols in the SJV, especially during the warm season. Aerosol simulations in the warm season are sensitive to the parameterization of dust emission in WRF-Chem. The GOCART (Goddard Global Ozone Chemistry Aerosol Radiation and Transport) dust scheme produces very little dust in the SJV, while the DUSTRAN (DUST TRANsport model) scheme overestimates dust emission. Vertical mixing of aerosols is not adequately represented in the model based on CALIPSO (CloudAerosol Lidar and Infrared pathfinder Satellite Observation) aerosol extinction profiles. Improved representation of dust emission and vertical mixing in the boundary layer is needed for better simulations of aerosols during the warm season in the SJV.
\end{abstract}

\section{Introduction}

The San Joaquin Valley (SJV) in the southern portion of the California Central Valley is surrounded by a coastal mountain range to the west and the Sierra Nevada range to the east. With cool wet winters and hot dry summers, the unique natural environment makes SJV one of the most productive agricultural regions in the world (SJV APCD, 2012 and references therein). However, SJV is also one of the most polluted regions in the US due to its unique geographical location. Frequent stagnant weather systems are conducive to air pollution formation, while the surrounding mountains block air flow and trap pollution. Large seasonal and spatial variation in aerosol occurrence and distribution is observed in the SJV. Although significant progress in improving local air quality in past decades has been achieved through strong emission controls, $\mathrm{PM}_{2.5}$ (particulate matter with a diameter $\leq 2.5 \mu \mathrm{m}$ ) concentrations in the SJV remain well above the National Ambient Air Quality Standards (NAAQS) threshold of $12 \mu \mathrm{g} \mathrm{m}^{-3}$ on an annual basis and $35 \mu \mathrm{g} \mathrm{m}^{-3}$ on a daily basis, occurring mainly during the cold season. Improved understanding of the aerosol variability and impacts is needed to provide further guidance for emission control strategies in the SJV.

Air quality models are a useful tool for understanding the formation and evolution of aerosols and their impacts on air quality, weather and climate. However, it is quite challenging to accurately simulate aerosol properties (Fast et al., 2014). Fast et al. (2014) summarized the factors contributing to the 
errors in regional-scale modeling of aerosol properties. They include (1) emission sources, (2) meteorological parameterizations, (3) representation of aerosol chemistry, (4) limited understanding of the formation processes of secondary organic aerosol (SOA), (5) spatial resolution and (6) boundary conditions.

As one of the advanced regional air quality models presently available to the community, the Weather Research and Forecasting model with Chemistry (WRF-Chem) has been widely used to study aerosols and their impacts on regional air quality, weather and climate (e.g., Misenis and Zhang, 2010; Zhang et al., 2010; Zhao et al., 2010, 2013a, b, 2014; Gao et al., 2011; Wu et al., 2011a, b, 2013; Fast et al., 2012, 2014; Scarino et al., 2014; Tessum et al., 2015; Campbell et al., 2016; Hu et al., 2016). For example, Fast et al. (2014) showed that WRF-Chem simulations at $4 \mathrm{~km}$ horizontal resolution captured the observed meteorology and boundary layer structure over California in May and June of 2010 and the spatial and temporal variations in aerosols were reasonably simulated. Aerosol simulations by WRF-Chem are usually sensitive to both local emission and long-range transport of aerosols from the boundary conditions provided by the global Model for Ozone and Related Chemical Tracers, version 4 (MOZART-4). With a similar model set-up, Zhao et al. (2013b) conducted a 1-year simulation at $12 \mathrm{~km}$ horizontal resolution and found that the WRF-Chem model represented the observed seasonal and spatial variation in surface particulate matter (PM) concentration over California. However, underestimation of elemental carbon (EC) and organic matter (OM) was noticed in the model simulation, with weak sensitivity to horizontal resolution.

In this study, we focus on simulating aerosol seasonal variability in the SJV, California, using similar model configurations to those used in Zhao et al. (2013b) and Fast et al. (2014). This paper serves as the first step for future investigation of the aerosol impact on regional climate and the water cycle in California. Previous studies have demonstrated that aerosols are better simulated at higher model resolution (Misenis and Zhang et al., 2010; Qian et al., 2010; Stround et al., 2011; Fountoukis et al., 2013). However, most regional climate studies are still performed with coarse model resolutions (of the order of $10 \mathrm{~km}$ ) due to the availability of computational resources. This study will investigate the sensitivity of aerosol simulations to horizontal resolution and identify optimal model physical choices for reasonable representation of aerosol variabilities in the SJV.

Another application of air quality modeling is to provide initial a priori fields for remote sensing retrievals. The WRFChem model has been proposed as an input for retrieval algorithms to be developed for the recently selected NASA MAIA (Multi-Angle Imager for Aerosols) mission, which aims to map PM component concentrations in major urban areas (including the SJV, a test bed for the MAIA retrieval algorithm development). A significant challenge for aerosol remote sensing in retrieving spatial information on specific aerosol types, especially near the surface, is caused by the lack of information on the vertical distribution of aerosols in the atmospheric column and limited instrument sensitivity to aerosol types over land. The WRF-Chem model will be used to provide near-real-time estimation of particle properties, aerosol layer heights and aerosol optical depths (AODs) to constrain the instrument-based PM retrievals. A reasonable estimate of aerosol properties from WRF-Chem is critical to ensuring retrieval speed and quality. Considering the sensitivity of WRF-Chem simulations to various factors such as initial and boundary conditions, model parameterizations and emission sources (e.g., Wu and Petty, 2010; Zhao et al., 2010, 2013a, b; Wu et al., 2011a, 2015; Fast et al., 2014; Campbell et al., 2016; Morabito et al., 2016), careful model evaluations are needed before the simulations can be used operationally for remote sensing retrievals. Thus, this study is important for the development of MAIA retrieval algorithms, which are critical to the success of the MAIA mission.

This paper is organized as follows. Section 2 describes observational datasets used for model evaluation. Section 3 provides the description of the WRF-Chem model and experiment setup. Model simulations and their comparison with observations are discussed in Sect. 4. Section 5 presents the conclusions.

\section{Observations}

\subsection{Column-integrated aerosol optical properties}

AOD is a measure of column-integrated light extinction by aerosols and a proxy for total aerosol loading in the atmospheric column. The Aerosol Robotic Network (AERONET) provides ground measurements of AOD every $15 \mathrm{~min}$ during daytime under clear skies (Holben et al., 1998), with an accuracy approaching \pm 0.01 (Eck et al., 1999; Holben et al., 2001; Chew et al., 2011). The monthly level 2.0 AOD product with cloud screening and quality control is used in this study. The Ångström exponent (AE) is an indicator of aerosol particle size. Small (large) AE values are generally associated with large (small) aerosol particles (Ångström, 1929; Schuster et al., 2006). The AE between 0.4 and $0.6 \mu \mathrm{m}$ is derived from AERONET observed AODs and is used to evaluate the model-simulated AE. For comparison with simulated AOD, AERONET AOD is interpolated to $0.55 \mu \mathrm{m}$ from 0.50 to $0.675 \mu \mathrm{m}$ using the $\mathrm{AE}$. In the $\mathrm{SJV}$, only one AERONET station at Fresno, California $\left(36.79^{\circ} \mathrm{N}\right.$, $119.77^{\circ} \mathrm{W}$ ), has regular observations throughout the California water year of 2013 (WY2013) from October 2012 to September 2013.

The Multiangle Imaging Spectroradiometer (MISR) (Diner et al., 1998) instrument onboard the Terra satellite has provided global coverage of AOD once a week since December 1999. The standard MISR retrieval algorithm provides AOD observations at $17.6 \mathrm{~km}$ resolution using $16 \times 16$ pixels 


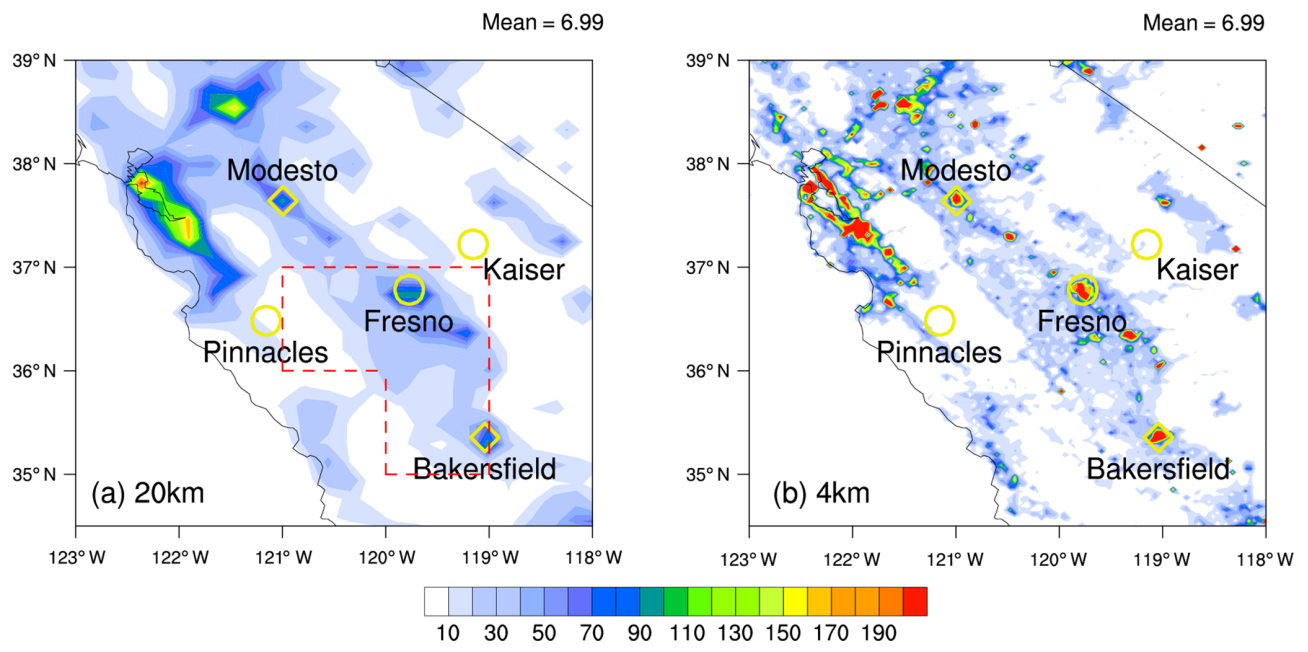

Figure 1. Daily mean anthropogenic $\mathrm{PM}_{2.5}$ emission rate $\left(\mu \mathrm{g} \mathrm{m}^{-2} \mathrm{~h}^{-1}\right)$ in (a) $20 \mathrm{~km}$ and (b) $4 \mathrm{~km}$ simulations. Domain-averaged emission rate is shown at the top right of each panel. Red dashed lines in (a) represent the region used for the domain averages in the discussions. Yellow circle: IMPROVE site; yellow diamond: EPA CSN site. Three urban sites: Fresno, Bakersfield and Modesto; two rural sites: Pinnacles and Kaiser.

of $1.1 \mathrm{~km} \times 1.1 \mathrm{~km}$ each. About $70 \%$ of MISR AOD retrievals are within $20 \%$ of the paired AERONET AOD, and about $50 \%$ of MISR AOD falls within $10 \%$ of the AERONET AOD, except in dusty and hybrid (smoke and dust) sites (Kahn et al., 2010). We use version 22 of the Level 3 monthly AOD product at $0.5^{\circ}$ resolution in this study.

\subsection{Surface mass concentration}

Surface $\mathrm{PM}_{2.5}$ speciation and $\mathrm{PM}_{10}$ (particulate matter with a diameter $\leq 10 \mu \mathrm{m}$ ) data are routinely collected by two national chemical speciation monitoring networks: the Interagency Monitoring of Protected Visual Environments (IMPROVE) and the $\mathrm{PM}_{2.5}$ National Chemical Speciation Network (CSN) operated by the Environmental Protection Agency (EPA) (Hand et al., 2011; Solomon et al., 2014). IMPROVE has collected $24 \mathrm{~h}$ aerosol speciation every third day at mostly rural sites since 1988 . The same frequency of aerosol speciation dataset has been collected at EPA CSN sites in urban and suburban areas since 2000. The observed organic carbon is converted to OM by multiplying by 1.4 (Zhao et al., 2013b; Hu et al., 2016). Some precursors of aerosol pollution (such as $\mathrm{NO}_{2}$ and $\mathrm{SO}_{2}$ ) are observed hourly by the EPA (data available at https://aqsdr1.epa.gov/ aqsweb/aqstmp/airdata/download_files.html) and are used in this study. Selected IMPROVE and EPA CSN sites used in this study are shown in Fig. 1a.

\subsection{Aerosol extinction profile}

The aerosol extinction coefficient profile reflects the attenuation of the light passing through the atmosphere due to the scattering and absorption by aerosol particles as a function of range. Version 3 Level $2532 \mathrm{~nm}$ aerosol extinction profiles derived from Cloud-Aerosol Lidar with Orthogonal Polarization (CALIOP) backscatter profiles collected onboard the Cloud-Aerosol Lidar and Infrared Pathfinder Satellite $\mathrm{Ob}$ servation (CALIPSO) satellite are used (Omar et al., 2009; Young and Vaughan, 2009). Seasonal mean profiles are derived for WY2013 based on the methodology outlined in Campbell et al. (2012), whereby quality-assurance protocols are applied to individual profiles before aggregating and averaging the data. We highlight that no individual profiles are included in the averages if the CALIOP Level 2 retrieval failed to resolve any extinction within the column, a potential issue for creating bias that has recently been described by Toth et al. (2017). Level $2532 \mathrm{~nm}$ aerosol extinction data classify aerosols into six types: clean marine, dust, polluted continental, clean continental, polluted dust and smoke. Dust and polluted dust are distinguished in the averages in this study for their seasonal contribution to total extinction and the vertical profile in the SJV.

\subsection{Meteorology}

AIRS (Atmospheric Infrared Sounder) onboard the Aqua satellite (Susskind et al., 2003; Divakarla et al., 2006) has provided global coverage of the tropospheric temperature and moisture at approximately 01:30 and 13:30 local time since 2002. AIRS retrievals have a RMSE of $\sim 1 \mathrm{~K}$ for temperature and $\sim 15 \%$ for water vapor (Divakarla et al., 2006). Level 3 monthly temperature and moisture retrievals (version 6) on a $1^{\circ} \times 1^{\circ}$ grid are used in this study. The vertical gradient of equivalent potential temperature $\left(\theta_{\mathrm{e}}\right)$ marks atmospheric stability and is computed from temperature and moisture profiles observed by AIRS. Vertical profiles from the $\mathrm{Eu}-$ ropean Center for Medium-Range Weather Forecasts Interim 
Re-Analysis (ERA-Interim; Dee et al., 2011) are also used for comparison. Surface observations, including air temperature, relative humidity $(\mathrm{RH})$ and wind speed, are routinely collected at the California Irrigation Management Information System (CIMIS; http://www.cimis.water.ca.gov/). Precipitation used in this study is the Climate Prediction Center (CPC) Unified Gauge-Based Analysis of Daily Precipitation product at $0.25^{\circ} \times 0.25^{\circ}$ resolution.

\section{Model description and experiment setup}

The WRF-Chem model Version 3.5.1 (Grell et al., 2005) updated by the Pacific Northwest National Laboratory (PNNL) is used in this study (Zhao et al., 2014). This study uses the CBM-Z (carbon bond mechanism) photochemical mechanism (Zaveri and Peters, 1999) coupled with the sectionalbin MOSAIC (Model for Simulating Aerosol Interactions and Chemistry) aerosol scheme (Zaveri et al., 2008) as the chemical driver. The major components of aerosols (nitrate, ammonium, EC, primary OM, sulfate, sea salt, dust, water and other inorganic matter) as well as their physical and chemical processes are simulated in the model. For computational efficiency, aerosol particles in this study are partitioned into four sectional bins with a dry diameter within $0.039-0.156,0.156-0.625,0.625-2.5$ and $2.5-10.0 \mu \mathrm{m}$. Zhao et al. (2013a) compared the impact of aerosol size partition on dust simulations. It showed that the four-bin approach reasonably produces dust mass loading and AOD compared with the eight-bin approach. The size distribution of the four-bin approach follows that of the eight-bin approach with coarser resolution, resulting in $\pm 5 \%$ difference in the ratio of $\mathrm{PM}_{2.5}$ dust $/ \mathrm{PM}_{10}$ dust in dusty regions (more large particles and less small particles). Dust number loading and absorptivity are biased high in the four-bin approach compared with the eight-bin approach.

Aerosols are considered to be spherical and internally mixed in each bin (Barnard et al., 2006; Zhao et al., 2013b). The bulk refractive index for each particle is calculated by volume averaging in each bin. Mie calculations as described by Ghan et al. (2001) are used to derive aerosol optical properties (such as extinction, single-scattering albedo and the asymmetry parameter for scattering) as a function of wavelength. Aerosol radiation interaction is included in the shortwave and longwave radiation schemes (Fast et al., 2006; Zhao et al., 2011). By linking simulated cloud droplet number with shortwave radiation and microphysics schemes, aerosol cloud interaction is effectively simulated in WRF-Chem (Chapman et al., 2009). Aerosol snow interaction is implemented in this version of WRF-Chem (Zhao et al., 2014) by considering aerosol deposition on snow and the subsequent radiative impacts through the SNICAR (SNow, ICe, and Aerosol Radiative) model (Flanner and Zender, 2005, 2006).
The model simulations start on 1 September 2012 and run continuously for 13 months. With the first month used for the model spin-up, our analysis focuses on WY2013 from October 2012 to September 2013. The model is configured with 40 vertical levels and a model top at $50 \mathrm{hPa}$. The vertical resolution from the surface to $1 \mathrm{~km}$ gradually increases from 28 to $250 \mathrm{~m}$. The model center is placed at $38^{\circ} \mathrm{N}, 121^{\circ} \mathrm{W}$, with $250 \times 350$ grid points at $4 \mathrm{~km}$ horizontal resolution (referred to as " $4 \mathrm{~km}$ " hereafter; Table 1), covering California and the surrounding area. To test the sensitivity of the aerosol simulations to horizontal resolution, one simulation with the same model settings and domain coverage is conducted at $20 \mathrm{~km}$ horizontal resolution (referred to as " $20 \mathrm{~km}$ " hereafter).

The physics parameterizations used in the simulations include the Morrison double-moment microphysics scheme (Morrison et al., 2009), Rapid Radiative Transfer Model for general circulation models (RRTMG) model shortwave and longwave radiation schemes (Iacono et al., 2008), and the Community Land Model (CLM) Version 4 land surface scheme (Lawrence et al., 2011). The Yonsei University (YSU) planetary boundary layer (PBL) scheme (Hong et al., 2006) is used in all of the simulations, except one sensitivity experiment that uses the ACM2 (Asymmetric Convective Model with non-local upward mixing and local downward mixing; Pleim, 2007) PBL scheme (referred to as "20km_P7" hereafter, Table 1). Previous studies showed that both the YSU and ACM2 schemes have good performance in simulating boundary layer properties (e.g., Hu et al., 2010; Xie et al., 2012; Cuchiara et al., 2014; Banks and Baldasano, 2016; Banks et al., 2016; Chen et al., 2017). Sub-grid convection, convective transport of chemical constituents and aerosols, and wet deposition from sub-grid convection are parameterized using the Grell 3-D ensemble cumulus scheme (Grell and Devenyi, 2002) in the $20 \mathrm{~km} \mathrm{simu-}$ lations, while convective processes are resolved in the $4 \mathrm{~km}$ simulations. The ERA-Interim reanalysis serves as the initial and boundary meteorological conditions for WRF-Chem. The MOZART-4 global chemical transport model (Emmons et al., 2010) is used for initial and boundary chemical conditions. Fast et al. (2014) found that the MOZART-4 model overestimates aerosols in the free troposphere over California, which is also found in one of our sensitivity experiments ("20km_BC1" in the Supplement). Following Fast et al. (2014), the chemical initial and boundary conditions from MOZART-4 are divided by 2 in all simulations except 20km_BC1.

Anthropogenic emissions are provided by US EPA 2005 National Emissions Inventory (NEI05), with area-type emissions on a structured $4 \mathrm{~km}$ grid and point-type emissions at specific latitude and longitude locations (US EPA, 2010). Aerosol emissions include $\mathrm{SO}_{4}, \mathrm{NO}_{3}, \mathrm{EC}$, organic aerosols, and total $\mathrm{PM}_{2.5}$ and $\mathrm{PM}_{10}$ masses, and 19 gases (including $\mathrm{SO}_{2}, \mathrm{NO}, \mathrm{NH}_{3}$, etc.) are emitted. Anthropogenic emissions are updated every hour to account for diurnal variability, while their seasonal variation is not considered in the 
Table 1. Experiment description.

\begin{tabular}{ll}
\hline Experiment ID & Experiment description \\
\hline $20 \mathrm{~km}$ & Simulation with the GOCART dust scheme at 20 km horizontal resolution. \\
20km_D2 & Same as 20km, but with the DUSTRAN dust scheme. \\
$20 \mathrm{~km} \_P 7$ & Same as 20km_D2, but with the ACM2 PBL scheme. \\
$4 \mathrm{~km}$ & Same as 20km, but at 4 km horizontal resolution. \\
$4 \mathrm{~km} \_D 2$ & Same as 4km, but with the DUSTRAN dust scheme. \\
\hline
\end{tabular}

simulations. A sensitivity experiment with 2011 NEI emissions ("20km_NEI11" in the Supplement) did not produce significantly different results from the 2005 NEI emissions. Biogenic emissions are calculated online using the Model of Emissions of Gases and Aerosols from Nature (MEGAN) (Guenther et al., 2006). Biomass burning emissions are obtained from the Global Fire Emissions Database version 2.1, with 8-day temporal resolution (Randerson et al., 2007) and monthly updates. Sea salt emissions are derived from the PNNL-updated sea salt emission scheme that includes the correction of particles with a radius less than $0.2 \mu \mathrm{m}$ (Gong, 2003) and dependence on sea surface temperature (Jaeglé et al., 2011).

Following Zhao et al. (2013b), dust emission is computed from the GOCART (Goddard Global Ozone Chemistry Aerosol Radiation and Transport) dust scheme (Ginoux et al., 2001) in the $20 \mathrm{~km}$ and $4 \mathrm{~km}$ simulations. The GOCART dust scheme estimates the dust emission flux $F$ as

$F=C S s_{\mathrm{p}} u_{10 \mathrm{~m}}^{2}\left(u_{10 \mathrm{~m}}-u_{\mathrm{t}}\right)$,

where $C$ is an empirical proportionality constant, $S$ is a source function for potential wind erosion that is derived from the $1^{\circ} \times 1^{\circ}$ GOCART database (Freitas et al., 2011), $s_{\mathrm{p}}$ is a fraction of each size class dust in emission, $u_{10 \mathrm{~m}}$ is $10 \mathrm{~m}$ wind speed and $u_{\mathrm{t}}$ is a threshold speed for dust emission.

As shown later, a significant amount of dust is observed in the SJV, whereas the GOCART dust scheme produces little dust. Two sensitivity experiments at $20 \mathrm{~km}$ and $4 \mathrm{~km}$ horizontal resolution (hereafter referred to as "20km_D2" and "4km_D2", respectively) are conducted by switching the dust emission scheme to the DUST TRANsport model (DUSTRAN) scheme (Shaw et al., 2008). The DUSTRAN scheme estimates $F$ as

$F=\alpha C u_{*}^{4}\left(1-\frac{f_{\mathrm{w}} u_{* \mathrm{t}}}{u_{*}}\right)$,

where $C$ is an empirical proportionality constant, $\alpha$ is the vegetation mask, $u_{*}$ is the friction velocity, $u_{* \mathrm{t}}$ is a threshold friction velocity and $f_{\mathrm{w}}$ is the soil wetness factor. The $C$ value in both GOCART and DUSTRAN is highly tunable for different regions. The original $C$ values, $1.0 \mu \mathrm{g} \mathrm{s}^{2} \mathrm{~m}^{-5}$ in GOCART (Ginoux et al., 2001) and $1.0 \times 10^{-14} \mathrm{~g} \mathrm{~cm}^{-6} \mathrm{~s}^{-3}$ in DUSTRAN (Shaw et al., 2008), are used in this study.

\section{Model simulation results}

Shown in Fig. 1a, our model domain includes three urban sites (Fresno, Bakersfield and Modesto) and two rural sites (Pinnacles and Kaiser) where surface measurements of aerosols are available. Because aerosol properties and model performance are similar at all urban sites, our discussion is focused on the results at Fresno and the simulations for other urban sites are provided in the Supplement. Model simulations in the rural areas are presented in the last subsection.

\subsection{Sensitivity to horizontal resolution}

Figure 1 features daily mean anthropogenic $\mathrm{PM}_{2.5}$ emission rates used in the $20 \mathrm{~km}$ and $4 \mathrm{~km}$ simulations, respectively. Although both emission rates are derived from the $4 \mathrm{~km}$ NEI05 dataset, localized high emission rates with sharp gradients are evident in urban areas from the $4 \mathrm{~km}$ simulation (Fig. 1b). The $20 \mathrm{~km}$ simulation exhibits lower emission rates in the urban areas with weaker gradients due to the reapportionment process (Fig. 1a). As precipitation is an important process that removes aerosols, we examine the simulated precipitation for the $20 \mathrm{~km}$ and $4 \mathrm{~km}$ runs and find that the $20 \mathrm{~km}$ simulation produces $51 \%$ more precipitation, although the domain-averaged precipitation is lower in the $20 \mathrm{~km}$ run than the $4 \mathrm{~km}$ run (Fig. $2 \mathrm{a}$ ).

Consistent with higher emission rates and lower precipitation at Fresno, the $4 \mathrm{~km}$ run simulates higher AOD than the $20 \mathrm{~km}$ run in the cold season (October-November-December and January-February-March; OND and JFM in Fig. 3). Averaged over a broad area encompassing Fresno and Bakersfield, the most polluted region in the SJV (red box in Fig. 1a), the AOD is 0.090 in the $4 \mathrm{~km}$ simulation and 0.073 in the $20 \mathrm{~km}$ simulation, a $23 \%$ difference. Compared to the MISR observations, the $4 \mathrm{~km}$ simulation reproduces the spatial distribution and magnitude of AOD in the cold season. However, the AOD difference between the $20 \mathrm{~km}$ and $4 \mathrm{~km}$ runs is small in the warm season (April-May-June and JulyAugust-September; AMJ and JAS in Fig. 3), and both runs underestimate AOD by $\sim 50 \%$ with respect to the MISR observations.

Comparing the point values at Fresno in the $4 \mathrm{~km}$ and $20 \mathrm{~km}$ simulations (Fig. 4a), we find similar results: the $4 \mathrm{~km}$ AOD is closer to the AERONET measurements and is about $23 \%$ higher than that in the $20 \mathrm{~km}$ run during the cold season, while 

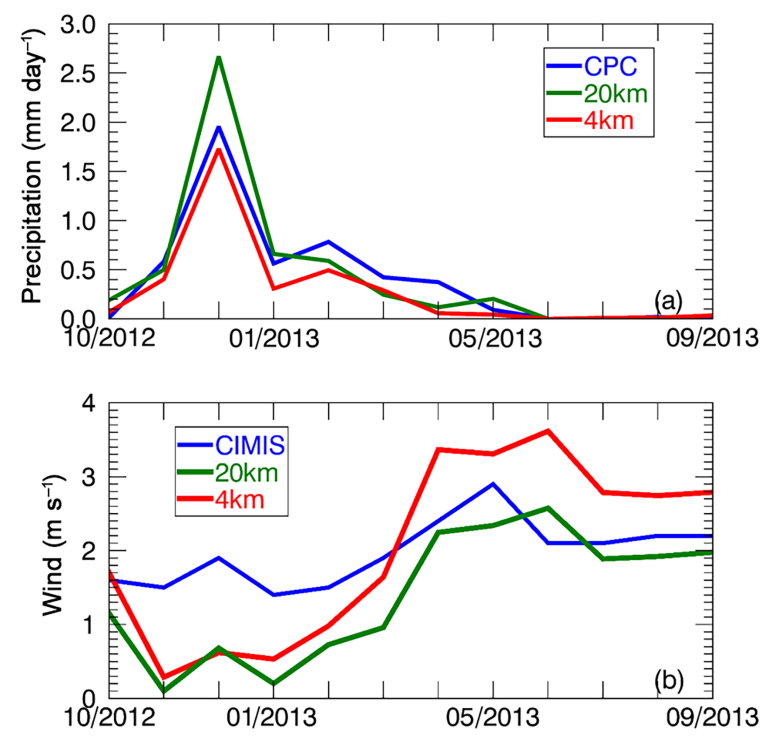

Figure 2. (a) Monthly precipitation $\left(\mathrm{mm} \mathrm{day}^{-1}\right)$ from CPC, $20 \mathrm{~km}$ and $4 \mathrm{~km}$; (b) monthly wind speed $\left(\mathrm{m} \mathrm{s}^{-1}\right)$ from CIMIS, $20 \mathrm{~km}$ and $4 \mathrm{~km}$. 4km_D2 (not shown) is similar to $4 \mathrm{~km}$.

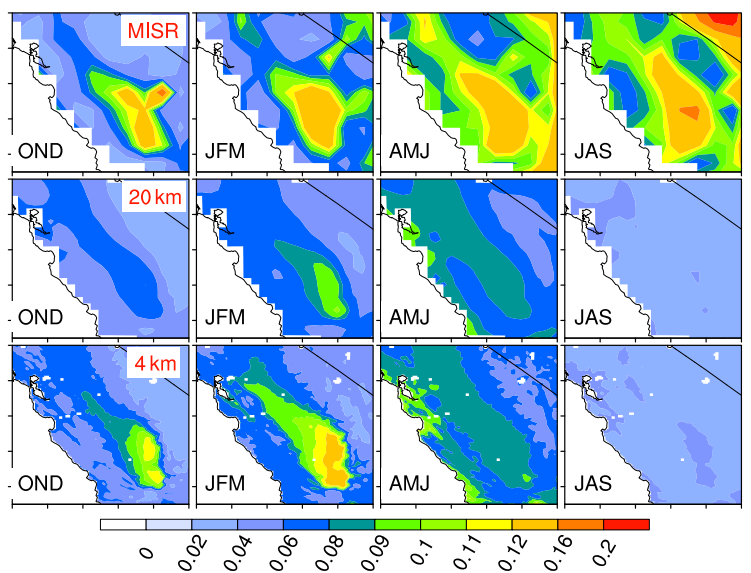

Figure 3. Spatial distribution of seasonal mean $550 \mathrm{~nm}$ AOD from MISR and the WRF-Chem $(20 \mathrm{~km}$ and $4 \mathrm{~km})$ simulations in WY2013. OND: October-November-December; JFM: JanuaryFebruary-March; AMJ: April-May-June; JAS: July-AugustSeptember.

both runs are biased low in AOD during the warm season. The different model sensitivities to horizontal resolution between the cold and warm seasons suggest that the dominant aerosol sources may be different for the two seasons. We will elaborate upon the aerosol composition in the following section. MISR and AERONET observations display weak seasonal AOD variation in the SJV and at Fresno, respectively, which is not well represented in the $20 \mathrm{~km}$ and $4 \mathrm{~km}$ simulations (Figs. 3 and 4a).

Aside from AOD, significant seasonal variability in AE (Fig. 4b) is shown at Fresno. AE exhibits a maximum of
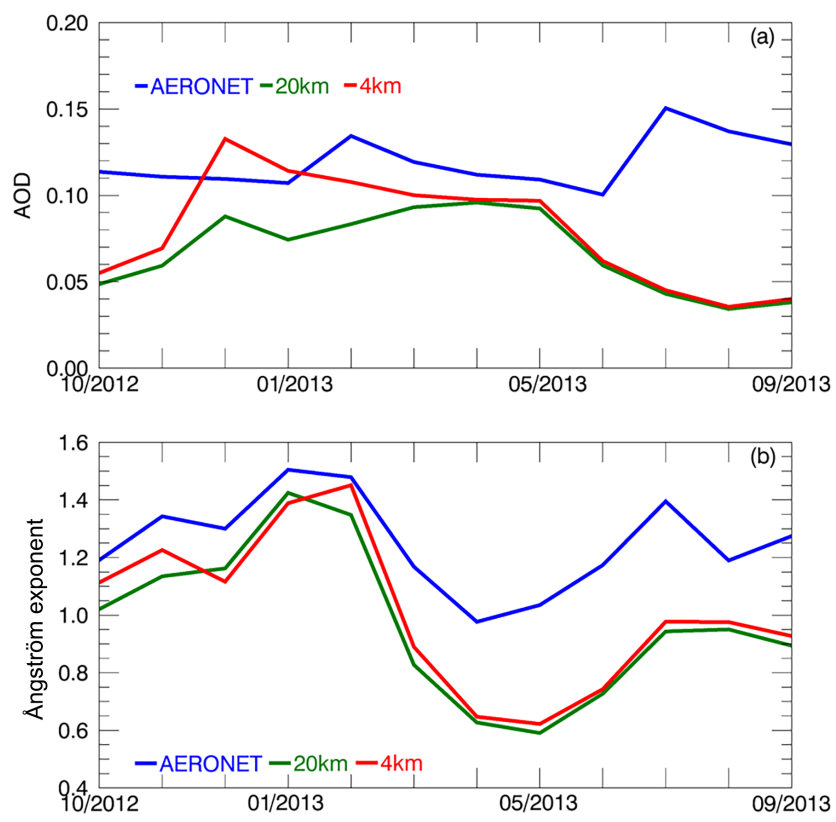

Figure 4. (a) Monthly mean $550 \mathrm{~nm}$ AOD; (b) monthly mean 400$600 \mathrm{~nm}$ Ångström exponent at Fresno, CA, from October 2012 to September 2013.

about 1.50 in January and a minimum of 0.98 in April, suggesting relatively small particles in the winter and large particles in the spring. A relatively large AE value of 1.40 (corresponding to small particles) is observed in July, possibly related to the wild fires in late July in the SJV. WRF-Chem captures the seasonal variability in the AE well, with a correlation of $0.90 \mathrm{in}$ both the $20 \mathrm{~km}$ and $4 \mathrm{~km}$ simulations. The magnitude of $\mathrm{AE}$ is also approximately simulated in the cold season, with a mean of $1.15(1.20)$ in the $20 \mathrm{~km}(4 \mathrm{~km})$ run compared to 1.33 in the observation. However, the simulated $\mathrm{AE}$ is underestimated by $\sim 30 \%$ in the warm season, indicating that the simulated particle size is biased high during this period.

Significant seasonal variability in $\mathrm{PM}_{2.5}$ is observed in the SJV urban areas (Figs. 5a and S4a and S5a). $\mathrm{PM}_{2.5}$ at Fresno peaks in January $\left(26.18 \mu \mathrm{g} \mathrm{m}^{-3}\right)$ and reaches a minimum of $7.03 \mu \mathrm{g} \mathrm{m}^{-3}$ in June, with an annual non-attainment value of $12.64 \mu \mathrm{g} \mathrm{m}^{-3}$ (Fig. 5a). Both the $20 \mathrm{~km}$ and $4 \mathrm{~km}$ runs approximately capture the observed seasonal variability in $\mathrm{PM}_{2.5}$, with a correlation around 0.90 (Table 2). In the cold season, the $4 \mathrm{~km}$ simulation overestimates $\mathrm{PM}_{2.5}$ by $27 \%$ while the $20 \mathrm{~km}$ simulation exhibits a low bias of $19 \%$ compared with IMPROVE observations at Fresno (Table 3). The $4 \mathrm{~km}$ simulation of $\mathrm{PM}_{10}$ is in good agreement with IMPROVE in the winter (December, January and February), but has significant low biases of between 30 and $85 \%$ in other months (Fig. 5b). The 20km simulation underestimates $\mathrm{PM}_{10}$ throughout WY2013.

$\mathrm{PM}_{2.5}$ is a mixture of nitrate $\left(\mathrm{NO}_{3}\right)$, ammonia $\left(\mathrm{NH}_{4}\right), \mathrm{OM}$, $\mathrm{EC}$, sulfate $\left(\mathrm{SO}_{4}\right)$, dust and other aerosols. High concen- 

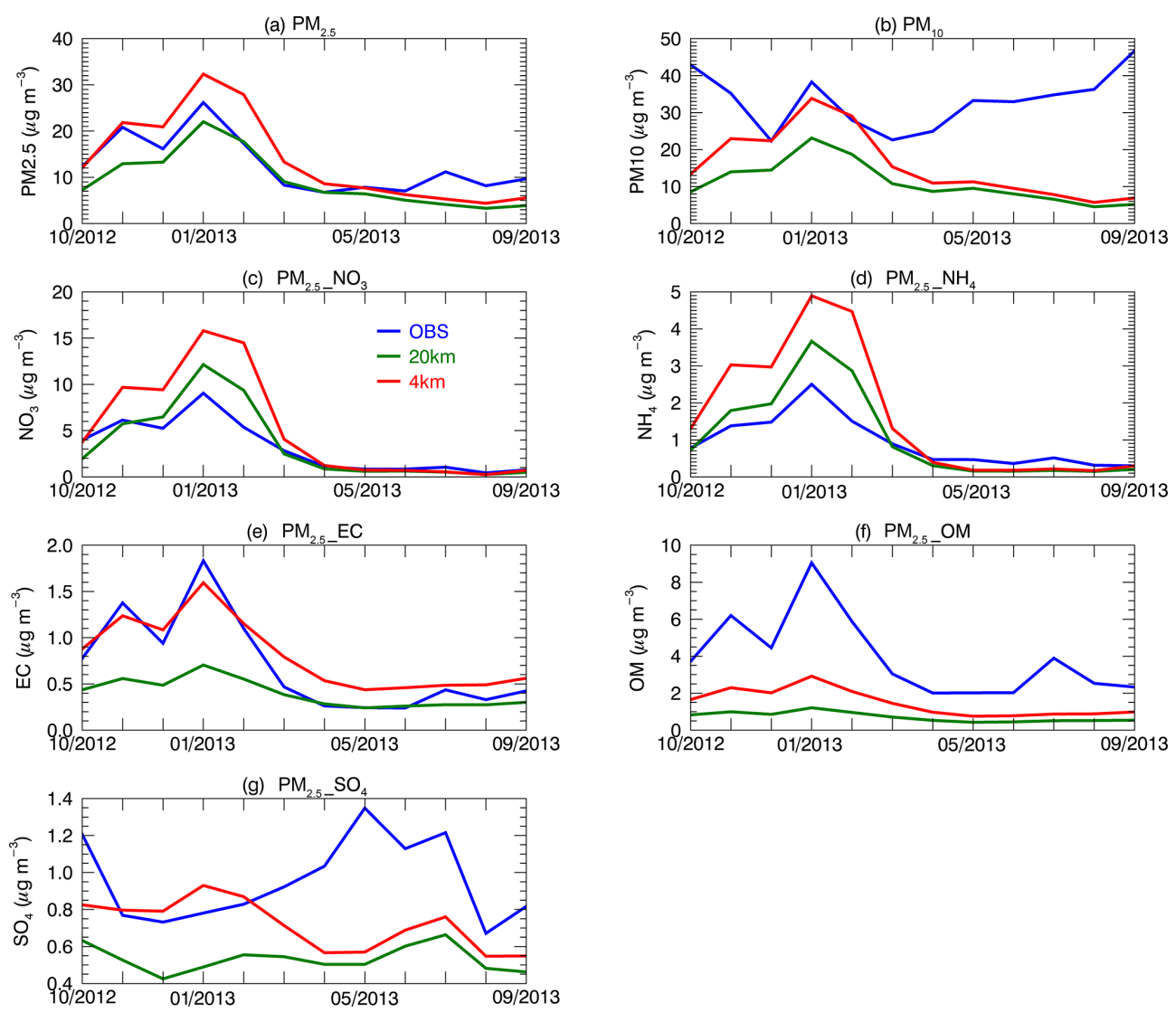

Figure 5. Aerosol mass $\left(\mu \mathrm{g} \mathrm{m}^{-3}\right)$ for different species from observations and the $20 \mathrm{~km}$ and $4 \mathrm{~km}$ simulations at Fresno, $\mathrm{CA}$. $\mathrm{NH}_{4}$ observations are from the EPA; other observations are from IMPROVE. $\mathrm{PM}_{2.5} \mathrm{NO}_{3}$ represents $\mathrm{NO}_{3}$ with a diameter $\leq 2.5 \mu$ m. Similar definition for $\mathrm{NH}_{4}$, $\mathrm{EC}, \mathrm{OM}$ and $\mathrm{SO}_{4}$ in the figures.

trations of $\mathrm{PM}_{2.5}$ are primarily the result of $\mathrm{NO}_{3}$ at Fresno (Fig. 5c). Both simulations produce the seasonal variability in $\mathrm{NO}_{3}$ with a correlation of 0.94 , but a high bias of $17 \%$ $(75 \%)$ is found in the $20 \mathrm{~km}(4 \mathrm{~km})$ simulation during the cold season. As one precursor of $\mathrm{NO}_{3}, \mathrm{NO}_{2}$ is underestimated by $43 \%$ in the $20 \mathrm{~km}$ run (Fig. 6a). The overestimation in $\mathrm{NO}_{3}$ and underestimation in $\mathrm{NO}_{2}$ suggest that the precursor emissions may not be the reason for the high biases in $\mathrm{NO}_{3} . \mathrm{NH}_{4}$ shows a similar performance to $\mathrm{NO}_{3}$, with an overestimation by $38 \%(111 \%)$ in the $20 \mathrm{~km}(4 \mathrm{~km})$ run during the cold seasons (Fig. 5d). As shown later in Sect. 4.3, both $\mathrm{NO}_{3}$ and $\mathrm{NH}_{4}$ simulations are quite sensitive to the PBL scheme applied.

$\mathrm{OM}$, the second largest species contributing to cold season $\mathrm{PM}_{2.5}$ in the SJV (Table 3), is significantly underestimated by $82 \%$ in the $20 \mathrm{~km}$ simulation (Fig. $5 \mathrm{f}$ ). The $4 \mathrm{~km}$ simulation produces higher OM, but it is still lower than the IMPROVE observations by $63 \%$. The underestimation of OM is expected because SOA processes are not included in our model infrastructure. Fast et al. (2014) used the simplified two-product volatility basis set parameterization to simulate equilibrium SOA partitioning in WRF-Chem although SOA was still underestimated in their simulation. Research
Table 2. Correlation with observations for different species at Fresno, CA.

\begin{tabular}{|c|c|c|c|c|c|}
\hline Species & $20 \mathrm{~km}$ & $4 \mathrm{~km}$ & 4km_D2 & 20km_D2 & 20km_P7 \\
\hline $\mathrm{PM}_{2.5}$ & 0.89 & 0.90 & 0.86 & 0.78 & 0.03 \\
\hline $\mathrm{PM}_{2.5} \mathrm{NO}_{3}$ & 0.94 & 0.95 & 0.94 & 0.94 & 0.91 \\
\hline $\mathrm{PM}_{2.5} \mathrm{NH}_{4}$ & 0.97 & 0.96 & 0.96 & 0.98 & 0.96 \\
\hline $\mathrm{PM}_{2.5} \mathrm{OM}$ & 0.93 & 0.93 & 0.94 & 0.93 & 0.91 \\
\hline $\mathrm{PM}_{2.5}$ ECC & 0.98 & 0.98 & 0.98 & 0.98 & 0.96 \\
\hline $\mathrm{PM}_{2.5} \mathrm{SO}_{4}$ & 0.63 & -0.16 & -0.14 & 0.61 & 0.63 \\
\hline $\mathrm{PM}_{2.5 \text { _dust }}$ & -0.55 & -0.50 & 0.48 & 0.55 & 0.36 \\
\hline $\mathrm{PM}_{10}$ & -0.25 & -0.23 & -0.08 & 0.01 & -0.03 \\
\hline
\end{tabular}

on how to correctly represent SOA processes in regional climate models remains ongoing.

Both the $20 \mathrm{~km}$ and $4 \mathrm{~km}$ simulations reproduce the seasonal variability in EC, with a correlation of 0.98 between the modeled and observed time series (Table 2). The $20 \mathrm{~km}$ simulation underestimates EC by $52 \%(16 \%)$ in the cold (warm) season (Fig. 5e and Table 3). The $4 \mathrm{~km}$ simulated EC $\left(1.12 \mu \mathrm{g} \mathrm{m}^{-3}\right)$ exhibits good agreement with IMPROVE $\left(1.08 \mu \mathrm{g} \mathrm{m}^{-3}\right)$ in the cold season, but overestimates EC by $53 \%$ in the warm season. 
Table 3. Surface aerosol mass $\left(\mu \mathrm{g} \mathrm{m}^{-3}\right)$ for different species at Fresno, CA.

\begin{tabular}{|c|c|c|c|c|c|c|c|c|c|c|c|c|}
\hline \multirow[t]{2}{*}{ Species } & \multicolumn{6}{|c|}{ Cold season } & \multicolumn{6}{|c|}{ Warm season } \\
\hline & OBS & $20 \mathrm{~km}$ & $4 \mathrm{~km}$ & 4km_D2 & 20km_D2 & 20km_P7 & OBS & $20 \mathrm{~km}$ & $4 \mathrm{~km}$ & 4km_D2 & 20km_D2 & 20km_P7 \\
\hline $\mathrm{PM}_{2.5}$ & 16.84 & 13.71 & 21.38 & 22.48 & 14.90 & 13.77 & 8.44 & 4.91 & 6.29 & 12.85 & 10.12 & 14.85 \\
\hline $\mathrm{PM}_{2.5} \mathrm{NO}_{3}$ & 5.43 & 6.36 & 9.54 & 9.22 & 6.22 & 3.16 & 0.84 & 0.55 & 0.69 & 0.79 & 0.66 & 0.57 \\
\hline $\mathrm{PM}_{2.5} \mathrm{NH}_{4}$ & 1.42 & 1.97 & 2.99 & 2.88 & 1.91 & 0.98 & 0.40 & 0.19 & 0.24 & 0.20 & 0.16 & 0.13 \\
\hline $\mathrm{PM}_{2.5} \mathrm{OM}$ & 5.39 & 0.92 & 2.07 & 2.07 & 0.93 & 1.04 & 2.47 & 0.49 & 0.87 & 0.87 & 0.50 & 0.55 \\
\hline $\mathrm{PM}_{2.5}$ EC & 1.08 & 0.52 & 1.12 & 1.13 & 0.52 & 0.58 & 0.32 & 0.27 & 0.49 & 0.49 & 0.27 & 0.30 \\
\hline $\mathrm{PM}_{2.5} \mathrm{SO}_{4}$ & 0.87 & 0.53 & 0.82 & 0.81 & 0.53 & 0.46 & 1.04 & 0.54 & 0.61 & 0.60 & 0.53 & 0.49 \\
\hline $\mathrm{PM}_{2.5 \text { _dust }}$ & 0.90 & 0.11 & 0.11 & 1.65 & 1.50 & 4.18 & 2.08 & 0.04 & 0.03 & 6.49 & 5.16 & 10.05 \\
\hline $\mathrm{PM}_{10}$ & 31.55 & 14.93 & 22.81 & 28.32 & 20.10 & 24.52 & 34.82 & 7.08 & 8.69 & 38.12 & 30.19 & 48.02 \\
\hline
\end{tabular}

The seasonal variability in $\mathrm{SO}_{4}$ at Fresno is very different from other $\mathrm{PM}_{2.5}$ species. It peaks in May at $1.35 \mu \mathrm{g} \mathrm{m}^{-3}$ and reaches the minimum of $0.67 \mu \mathrm{g} \mathrm{m}^{-3}$ in August (Fig. 5g). The $20 \mathrm{~km}$ simulated $\mathrm{SO}_{4}$ exhibits good correlation of 0.63 with the observation (Table 2), but is biased low by 28 to $63 \%$ throughout WY2013 (Fig. 5g). Although the observed $\mathrm{SO}_{2}$, the precursor of $\mathrm{SO}_{4}$, has approximately similar seasonal variation to the observed $\mathrm{SO}_{4}$ (Fig. 6b), the $20 \mathrm{~km}$ simulated seasonal variability in $\mathrm{SO}_{2}$ resembles other anthropogenic emissions, with high values in the cold season and low values in the warm season, out of phase with the simulated $\mathrm{SO}_{4}$ and the observed $\mathrm{SO}_{2}$. The $4 \mathrm{~km}$ simulation produces higher $\mathrm{SO}_{4}$ than the $20 \mathrm{~km}$ run, resulting in better agreement with the observation $\left(0.82 \mu \mathrm{g} \mathrm{m}^{-3}\right.$ vs. $0.87 \mu \mathrm{g} \mathrm{m}^{-3}$ ) during the cold season (Fig. $5 \mathrm{~g}$ and Table 3). However, the $4 \mathrm{~km}$ run produces an increase in $\mathrm{SO}_{4}$ by only $13 \%$ comparing to the $20 \mathrm{~km}$ run in the warm season, resulting in a correlation of -0.16 between the $4 \mathrm{~km}$ simulation and the observation.

To explore the possible cause for the underestimation of $\mathrm{SO}_{4}$ and $\mathrm{SO}_{2}$ in the warm season in both the $20 \mathrm{~km}$ and $4 \mathrm{~km}$ simulations, we conduct a sensitivity experiment with different chemical boundary conditions from the baseline runs (20km_BC1 in the Supplement). We find that $\mathrm{SO}_{4}$ in the $\mathrm{SJV}$ is partly contributed to by marine intrusions (the different chemical boundary conditions between 20km_BC1 and 20km_D2) throughout the year (Fig. S2g), as pointed out by Fast et al. (2014). Including the marine intrusions, the $20 \mathrm{~km} \_$BC1-simulated $\mathrm{SO}_{4}$ tracks the observation at a correlation of 0.78 . Doubled chemical boundary conditions in the $20 \mathrm{~km}$ simulation result in a $41 \%$ increase in $\mathrm{SO}_{4}$ at Fresno, with a stronger increase in the warm season. Compared to the observed $\mathrm{SO}_{4}$ of $1.04 \mu \mathrm{g} \mathrm{m}^{-3}$ in the warm season, the simulated $\mathrm{SO}_{4}$ of $0.79 \mu \mathrm{g} \mathrm{m}^{-3}$ in the run is closer to the observation than that simulated in the 20km_D2 run $\left(0.53 \mu \mathrm{g} \mathrm{m}^{-3}\right)$. The relative contributions of local emissions and remote transports (as well as other emission sources, such as wild fires) to $\mathrm{SO}_{4}$ concentrations in different seasons of the SJV require further investigation.

Overall, the $4 \mathrm{~km}$ simulation produces higher AOD and surface PM than the $20 \mathrm{~km}$ simulation in urban areas of the
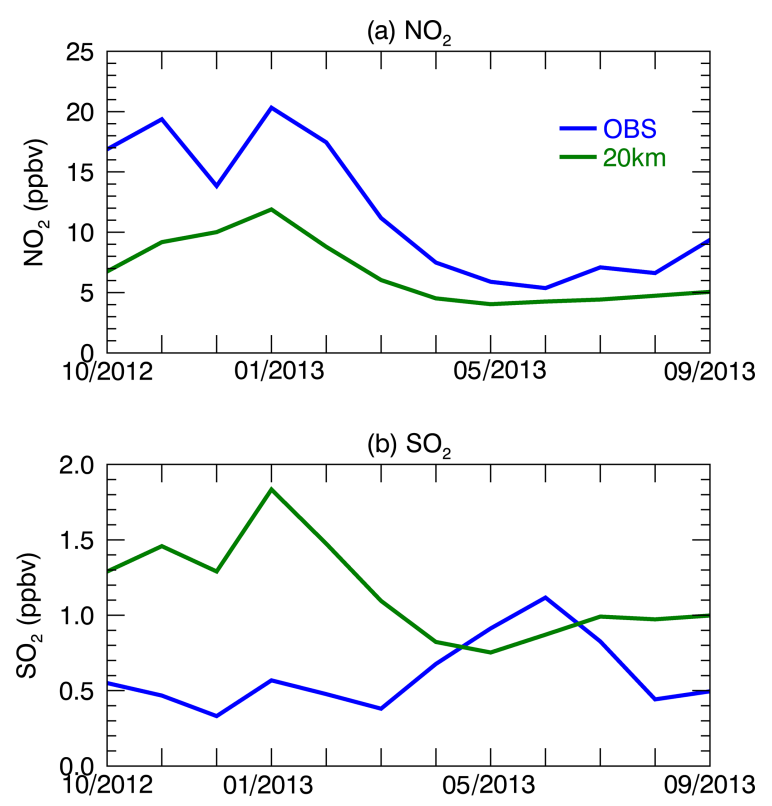

Figure 6. (a) $\mathrm{NO}_{2}$ and (b) $\mathrm{SO}_{2}$ from the $\mathrm{EPA}(\mathrm{OBS})$ and the $20 \mathrm{~km}$ run at Fresno, CA.

SJV, especially during the cold season, resulting in better agreement with satellite and surface observations than the $20 \mathrm{~km}$ simulation. Both the $20 \mathrm{~km}$ and $4 \mathrm{~km}$ simulations approximately capture the seasonal variability in $\mathrm{PM}_{2.5}$ and most of its speciation. However, significant low biases of $\mathrm{AOD}$ and $\mathrm{PM}_{10}$ are found during the warm season in both simulations. The underestimation also exists in a sensitivity experiment (not shown) with the same model setups except initialized in April, indicating that the identified model biases during the warm season are not caused by potential model drift after a relatively long simulation period. The relatively good performance in simulating $\mathrm{PM}_{2.5}$ but not $\mathrm{PM}_{10}$ during the warm season suggests that coarse aerosol particle mass $(\mathrm{CM} ; 10 \mu \mathrm{m} \geq$ particulate matter with a diameter $>2.5 \mu \mathrm{m})$, mainly dust in the SJV, is not properly represented in the model. The impact of dust parameterizations is investigated in the $4 \mathrm{~km} \_\mathrm{D} 2$ experiment. 

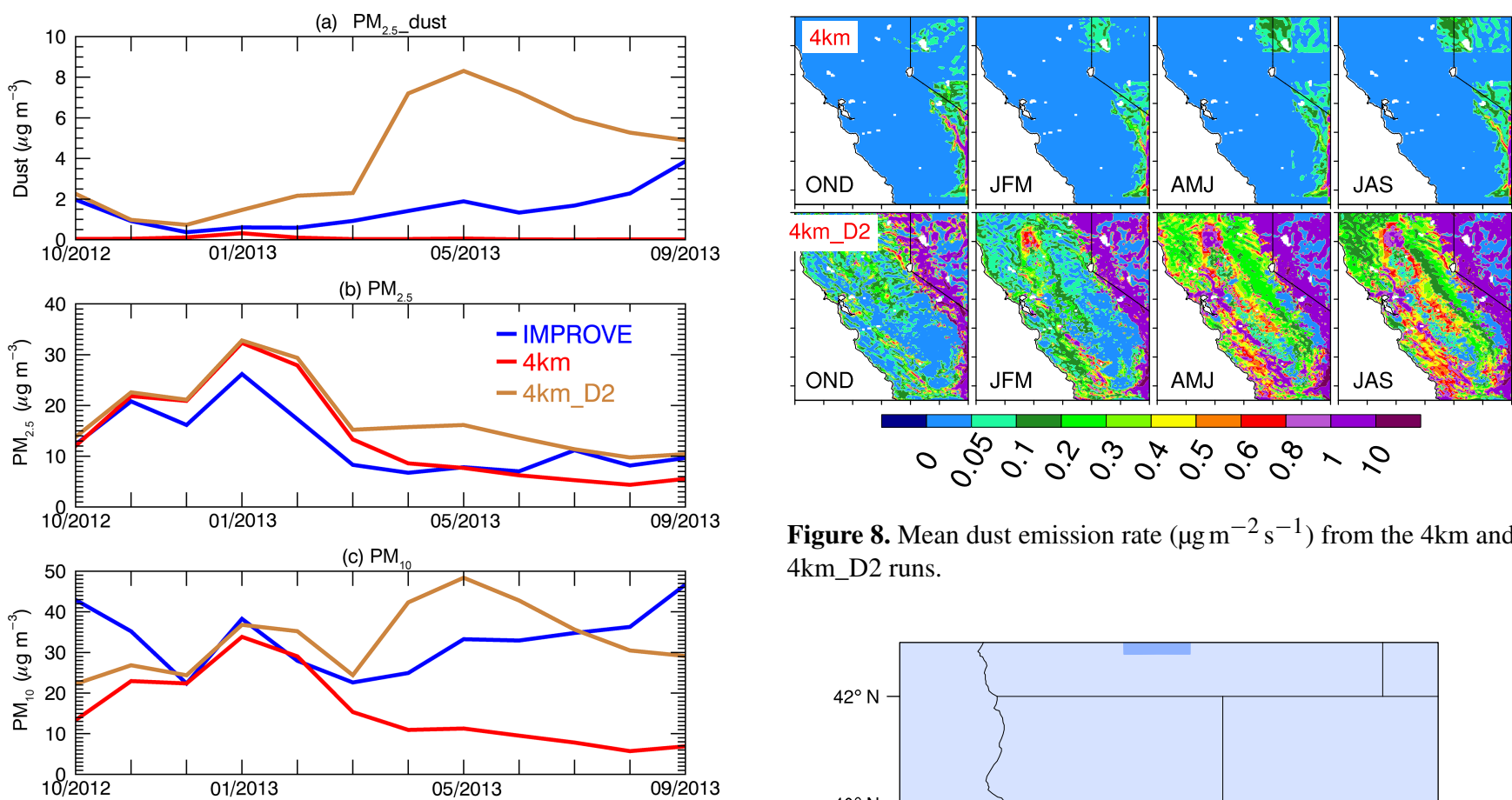

Figure 8. Mean dust emission rate $\left(\mu \mathrm{g} \mathrm{m}^{-2} \mathrm{~s}^{-1}\right)$ from the $4 \mathrm{~km}$ and $4 \mathrm{~km} \_\mathrm{D} 2$ runs.

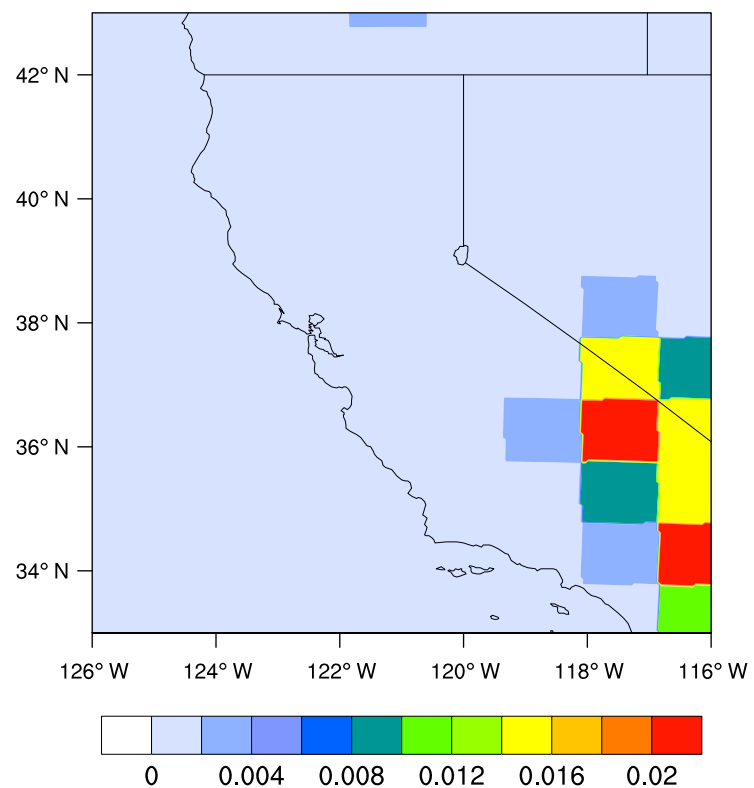
in Fig. 8). Conversely, the dust emission rate in the $4 \mathrm{~km}$ D2 run is significantly higher than the $4 \mathrm{~km}$ run. We have found that the source function, $S$, for potential wind erosion in the SJV is set to zero in the $1^{\circ} \times 1^{\circ}$ GOCART dataset used for the $4 \mathrm{~km}$ simulation (Fig. 9). An updated source function, $S$, at higher resolution is needed for the GOCART dust scheme to correctly represent dust emissions in the SJV.

The 4km_D2 simulation reproduces the amount of $\mathrm{PM}_{2.5}$ _dust in OND (Fig. 7a). However, it overestimates $\mathrm{PM}_{2.5}$ dust by up to a factor of 3 in the warm season, resulting in an overestimation of $\mathrm{PM}_{2.5}$ by $52 \%$ (Fig. $7 \mathrm{~b}$ and Table 3). $\mathrm{PM}_{2.5}$ _dust is not sensitive to long-range transport (from chemical boundary conditions in the model simulation; Fig. S2h). Both the $4 \mathrm{~km}$ and $4 \mathrm{~km} \_\mathrm{D} 2$ simulations capture the seasonal variability in $\mathrm{PM}_{2.5}$, but not that in $\mathrm{PM}_{10}$ (Fig. 7c). The magnitude of $\mathrm{PM}_{10}$ in the $4 \mathrm{~km} \_\mathrm{D} 2$ run is larger than the $4 \mathrm{~km}$ simulation. $\mathrm{PM}_{10}$ in the $4 \mathrm{~km} \_\mathrm{D} 2$ run is overestimated in AMJ but underestimated in JAS, leading to a comparable season mean of $38.12 \mu \mathrm{g} \mathrm{m}^{-3}$ with IMPROVE ob-

Figure 9. Fraction of erodible surface in the GOCART dataset used in this study.

serving $34.82 \mu \mathrm{g} \mathrm{m}^{-3}$. The overestimation of AMJ $\mathrm{PM}_{10}$ and $\mathrm{PM}_{2.5}$ dust in the $4 \mathrm{~km} \_\mathrm{D} 2$ run is likely associated with the high bias in the simulated wind speed (Fig. 2b).

As for the relative contribution of different aerosol species, IMPROVE observations at Fresno show that $\mathrm{NO}_{3}$ is the primary contributor $(32.3 \%)$ to $\mathrm{PM}_{2.5}$, while only $5.3 \%$ of $\mathrm{PM}_{2.5}$ is dust in the cold season (panel 1 of Fig. 10). Both the $4 \mathrm{~km}$ and $4 \mathrm{~km} \_\mathrm{D} 2$ runs roughly reproduce the relative contributions to $\mathrm{PM}_{2.5}$ in the cold season, with an overestimation of $\mathrm{NO}_{3}$ and $\mathrm{NH}_{4}$ and an underestimation of $\mathrm{OM}$, consistent with the time series in Fig. 5. Relative contributions of dust to $\mathrm{PM}_{2.5}$ are better simulated in the 4km_D2 run $(7.3 \%)$ than the $4 \mathrm{~km}$ one $(<1.0 \%)$. IMPROVE shows that $46.6 \%$ of $\mathrm{PM}_{10}$ is $\mathrm{CM}$ in the cold season (panel 2 of 


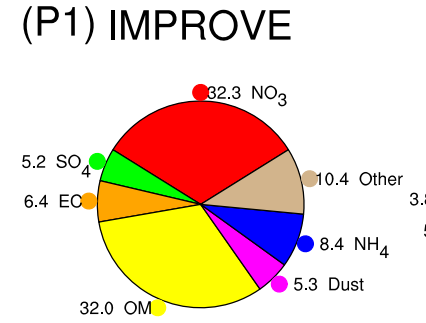

(P2)

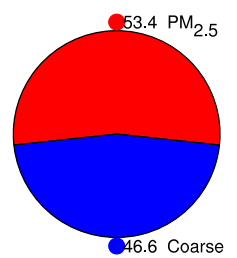

(P3)
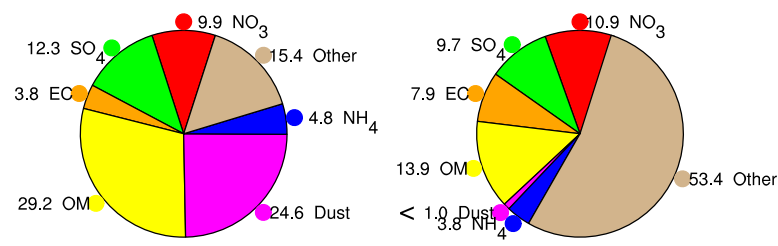

(P4)

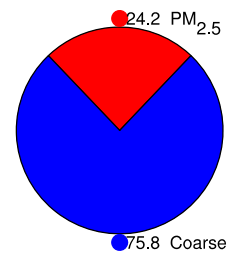

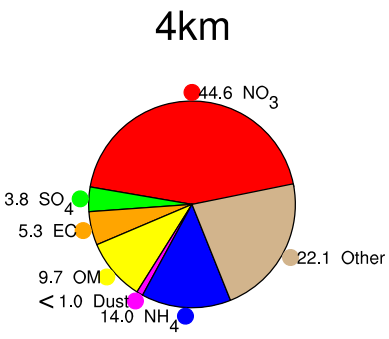
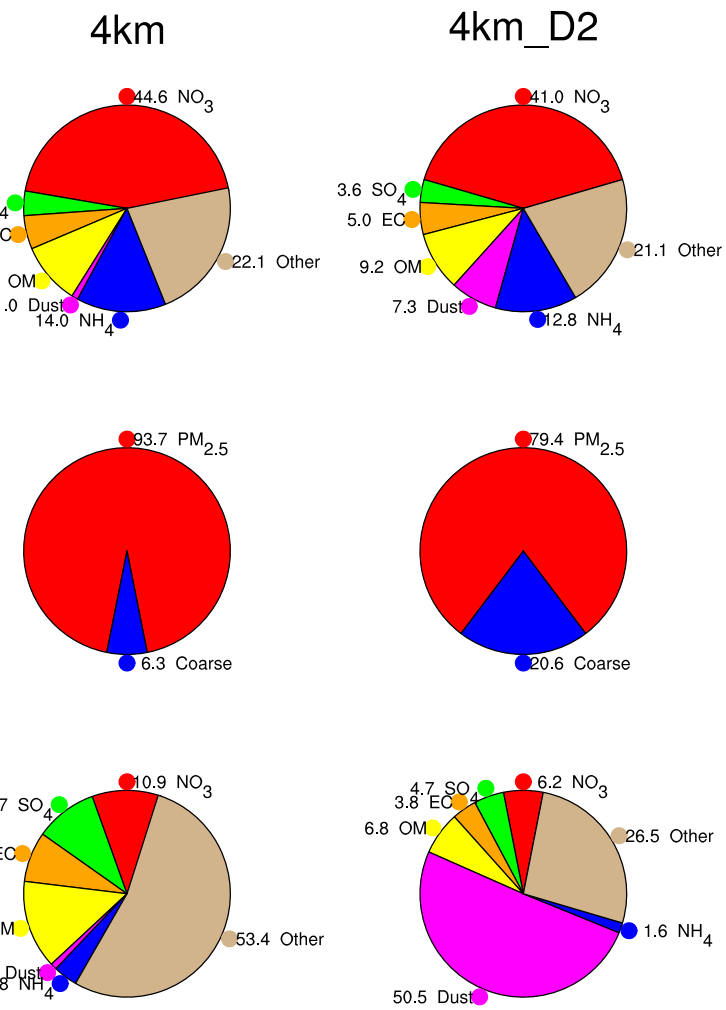

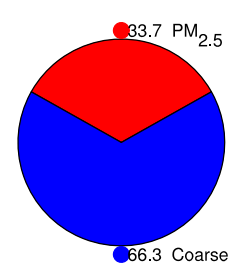

Figure 10. Relative contribution (\%) of aerosol species from IMPROVE and the WRF-Chem (4km and 4km_D2) simulations at Fresno, CA, in WY2013. (Panel 1) Contribution to $\mathrm{PM}_{2.5}$ in the cold season; (panel 2) relative contribution of $\mathrm{PM}_{2.5}$ and coarse mass (CM) to $\mathrm{PM}_{10}$ in the cold season; (panel 3) same as panel 1 but in the warm season; (panel 4) same as Panel 2 but in the warm season. "Other" refers to the difference of $\mathrm{PM}_{2.5}$ total mass and specified $\mathrm{PM}_{2.5}\left(\mathrm{NO}_{3}, \mathrm{NH}_{4}, \mathrm{OM}, \mathrm{EC}, \mathrm{SO}_{4}\right.$ and dust).

Fig. 10). Both the $4 \mathrm{~km}(6.3 \%)$ and $4 \mathrm{~km} \_\mathrm{D} 2(20.6 \%)$ runs underestimate the contribution of $\mathrm{CM}$ to $\mathrm{PM}_{10}$, mainly in October and November. In the warm season, dust (24.6\%) becomes the primary contributor to $\mathrm{PM}_{2.5}$, while the contribution from $\mathrm{NO}_{3}$ decreases to $9.9 \%$ in IMPROVE observations (panel 3 of Fig. 10). Almost no $\mathrm{PM}_{2.5}$ dust is simulated in the $4 \mathrm{~km}$ run, while too much $\mathrm{PM}_{2.5}$ _dust is produced in the $4 \mathrm{~km} \_\mathrm{D} 2(50.5 \%)$ run during the warm season. The relative contribution of $\mathrm{CM}$ to $\mathrm{PM}_{10}$ is too small $(27.6 \%)$ in the $4 \mathrm{~km}$ run, while the $4 \mathrm{~km} \_\mathrm{D} 2$ run reflects a better relative contribution of $66.3 \%$ as compared to IMPROVE-observed $75.8 \%$ (panel 4 of Fig. 10).

AOD simulations are improved in the 4km_D2 experiment (Fig. 11), with better agreement found for MISR (Fig. 3) in AMJ. AOD (0.114) in the 4km_D2 run is comparable

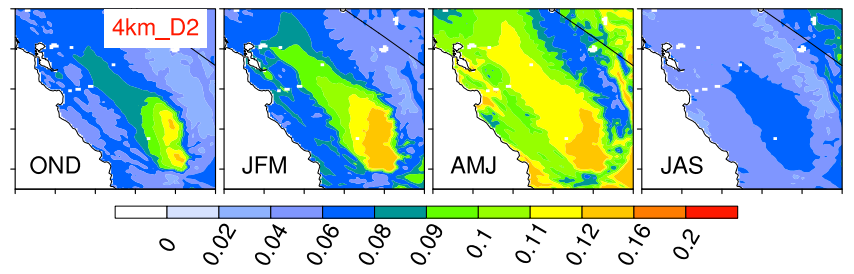

Figure 11. Spatial distribution of seasonal mean $550 \mathrm{~nm}$ AOD from the 4km_D2 run in WY2013.

to observations (0.131) in AMJ but are still underestimated by $53 \%$ in JAS. Consistent with AOD, the vertical distribution of aerosol extinction is reasonably simulated during the cold season in the WRF-Chem simulations, while large 
discrepancies are found in the warm season (Fig. 12). As observed by CALIOP at $532 \mathrm{~nm}$, aerosols are confined below $1 \mathrm{~km}$ in the cold season and decrease sharply with height. During AMJ, aerosols are well mixed between the surface and the altitude of $1.5 \mathrm{~km}$ and then gradually decrease with height. During JAS, the well-mixed aerosol layer is shallower than that in AMJ and the vertical profile of aerosol extinction is in-between the cold season and AMJ. Model simulations roughly capture the bottom-heavy structure of the extinction profiles observed by CALIOP especially in the cold season, but significant biases exist. One common problem for all four seasons is the low bias in the boundary layer and high bias in the free atmosphere. Similar discrepancy between the model simulations and CALIOP is shown in other studies (Wu et al., 2011a; Hu et al., 2016). The model does not capture the well-mixed aerosol layer during AMJ. The difference in the aerosol extinction profiles between the $4 \mathrm{~km}$ and $4 \mathrm{~km} \_\mathrm{D} 2$ runs is small during the cold season.

Dust in the boundary layer is a primary factor contributing to aerosol extinction in the SJV, as illustrated by the differences between the bulk seasonal CALIOP mean profile and those excluding the contributions of the dust and polluted dust (CALIOP_nodust) profiles (Fig. 12). Simulated aerosol extinction falls between the two in all seasons, suggesting that dust is the primary factor contributing to the model biases in aerosol extinction. Although a small portion of $\mathrm{PM}_{2.5}$ is dust in the cold season, it contributes to about $50 \%$ of total aerosol extinction (Fig. 12a and b). A predominant portion of aerosol extinction in the lower troposphere is contributed by dust in the warm season (Fig. 12c and d). There, the $4 \mathrm{~km} \_\mathrm{D} 2$ simulation produces higher aerosol extinction between 0.3 and $3 \mathrm{~km}$ than the $4 \mathrm{~km}$ simulation, although it is still lower than CALIOP. The simulated aerosol extinction in the free troposphere is close to or larger than CALIOP, suggesting that aerosols transported from remote areas through chemical boundary conditions (e.g., the differences between the 20km_BC1 and 20km_D2 runs in Fig. S3) may not be the major factors contributing to the underestimation of dust between 0.3 and $3 \mathrm{~km}$ in the SJV.

Overall, the poor simulations of dust play a dominant role in the low bias of aerosols in the boundary layer during the warm season. Both the GOCART and DUSTRAN dust emission schemes used in this study have difficulties in reproducing dust emissions in the SJV, with an underestimation in GOCART and an overestimation in DUSTRAN (Fig. 7). Improvement on the dust emission schemes is needed for capturing the seasonal variability in aerosols in the SJV.

\subsection{The role of meteorology}

The WRF-Chem simulations approximately reproduce the seasonal variations in meteorological variables near the surface (correlations $>0.80$ ), including temperature, $\mathrm{RH}$, wind speed and precipitation (Fig. S6 and Table S1). All of the model simulations exhibit warm and dry biases near the sur-
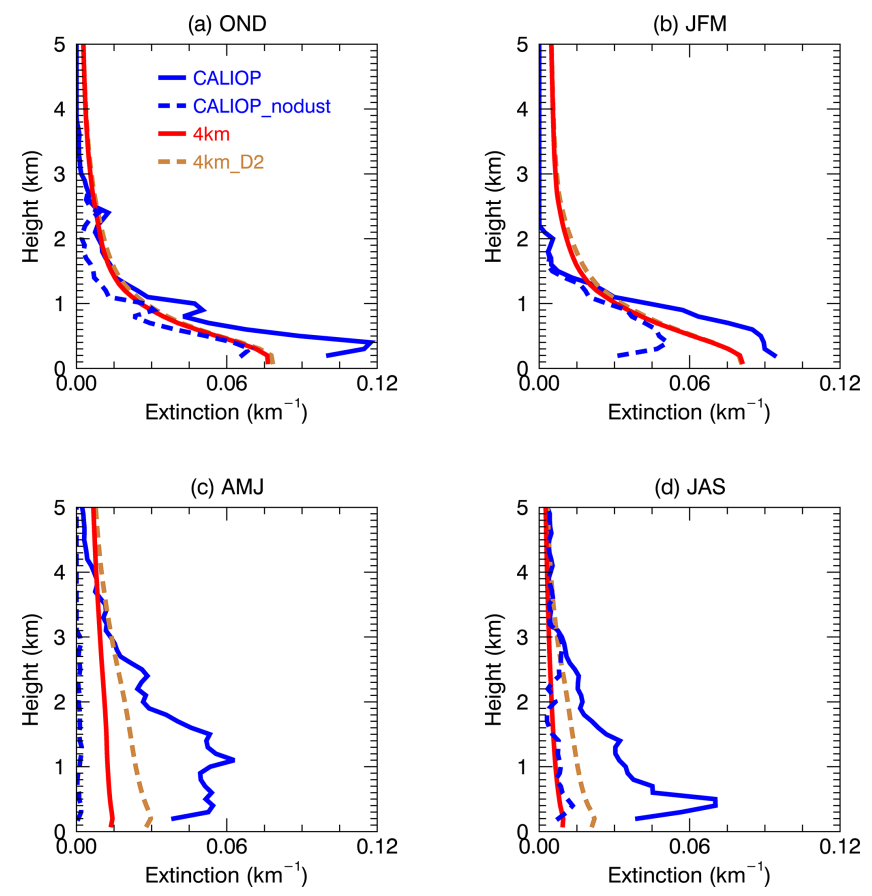

Figure 12. Vertical distribution of seasonal mean $532 \mathrm{~nm}$ aerosol extinction coefficient $\left(\mathrm{km}^{-1}\right)$ from CALIOP (blue) and the WRFChem (4km and 4km_D2) simulations over the red box region in Fig. 1a in WY2013. Blue dashed lines (CALIOP_nodust) represent the CALIOP profiles without dust (dust and polluted dust). (a) OND

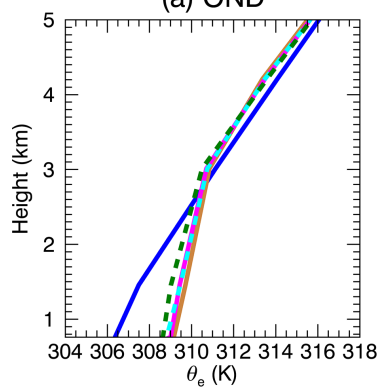

(c) AMJ

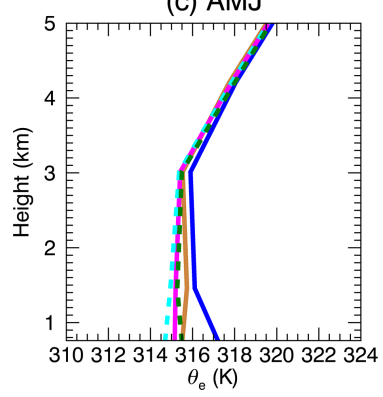

(b) JFM

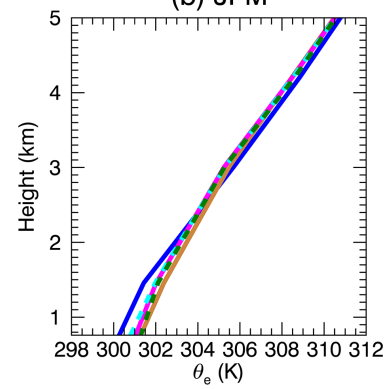

(d) JAS

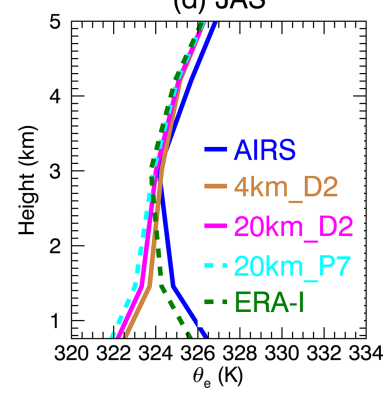

Figure 13. Vertical distribution of season mean equivalent potential temperature $\left(\theta_{\mathrm{e}} ; \mathrm{K}\right)$ from AIRS, ERA-Interim (ERA-I) and the WRF-Chem (4km_D2, 20km_D2 and 20km_P7) simulations over the red box region in Fig. 1a in WY2013. The 4km run (not shown) is similar to the $4 \mathrm{~km} \_\mathrm{D} 2$ run. 

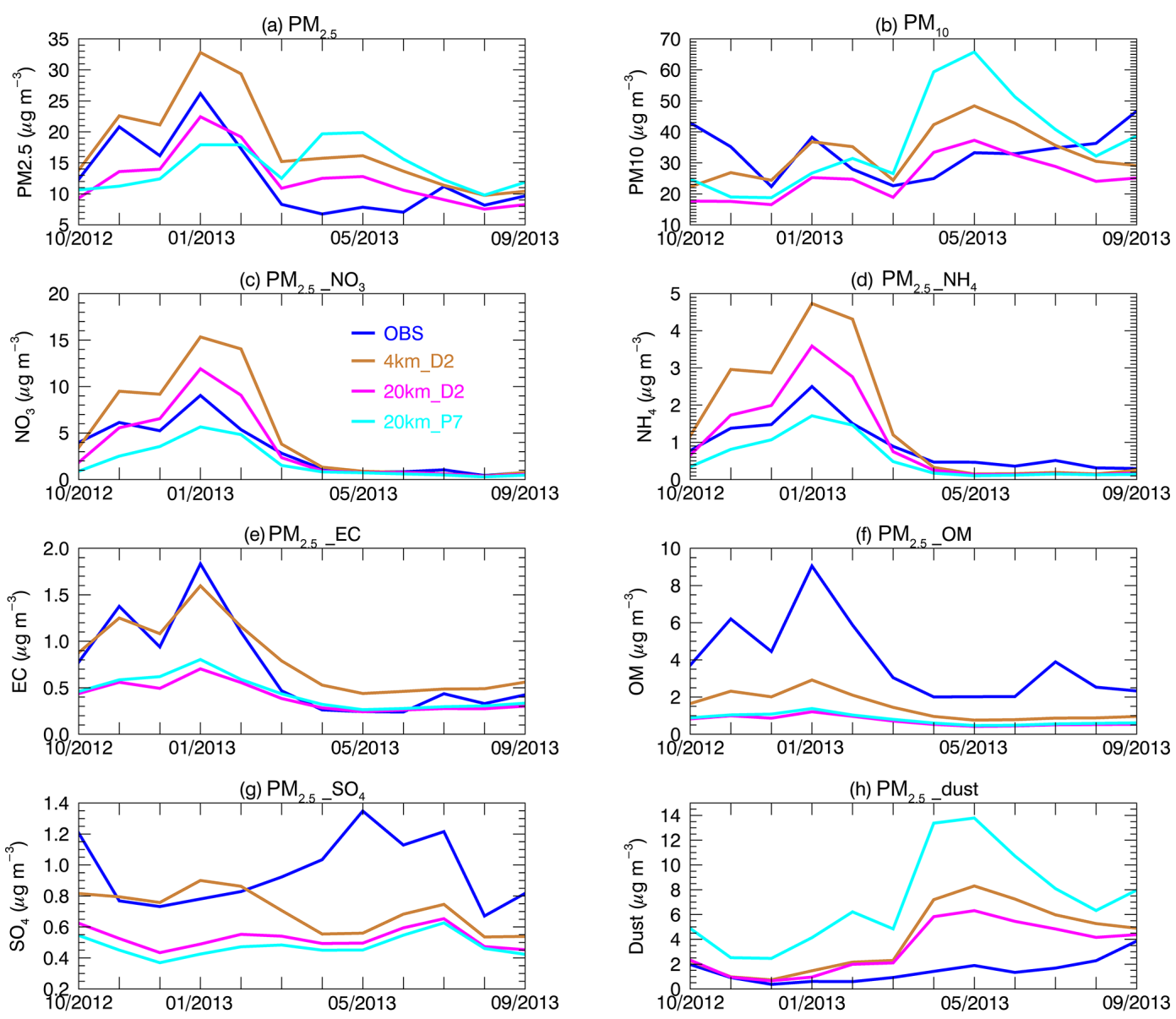

Figure 14. Aerosol mass $\left(\mu \mathrm{g} \mathrm{m}^{-3}\right)$ for different species from OBS, the $4 \mathrm{~km} \_\mathrm{D} 2,20 \mathrm{~km} \_\mathrm{D} 2$ and $20 \mathrm{~km} \_\mathrm{P} 7$ simulations at Fresno, CA. NH 4 observations are from the EPA; other observations are from IMPROVE. $\mathrm{PM}_{2.5} \mathrm{NO}_{3}$ represents $\mathrm{NO}_{3}$ with a diameter $\leq 2.5 \mu$ m. Similar definition for $\mathrm{NH}_{4}, \mathrm{EC}, \mathrm{OM}, \mathrm{SO}_{4}$ and dust in the figures.

face and in the boundary layer, with cold and wet biases in the free atmosphere (Figs. S6-S8 and Table S2). The dry bias in the $4 \mathrm{~km} \_\mathrm{D} 2$ run is about $10 \%$ near the surface throughout WY2013. Due to the relative dry environment $(\mathrm{RH}<50 \%)$ in the warm season, the underestimation of boundary layer aerosol extinction and column-integrated AOD is unlikely caused by the hygroscopic effects (Feingold and Morley, 2003). In the cold season, the surface wind speed is underestimated by $0.67 \mathrm{~m} \mathrm{~s}^{-1}\left(1.00 \mathrm{~m} \mathrm{~s}^{-1}\right)$ in the $4 \mathrm{~km} \_\mathrm{D} 2$ (20km_D2) runs. In the warm season, the $4 \mathrm{~km} \_\mathrm{D} 2$ run overestimates wind speed by $0.78 \mathrm{~m} \mathrm{~s}^{-1}$, while the $20 \mathrm{~km} \_\mathrm{D} 2$ run has an underestimation of $0.16 \mathrm{~m} \mathrm{~s}^{-1}$. These results suggest that wind speed is not a major factor contributing to the low biases of aerosols in the boundary layer between 0.3 and $3 \mathrm{~km}$. Furthermore, the seasonal variability in precipitation is well captured in the simulations, while the magnitude of precipitation is weaker than the observations during the warm season (Table S2). Thus, we conclude that wet removal processes would not be a primary reason for the aerosol biases in the warm season.
In the warm season, more aerosols are observed above $1.5 \mathrm{~km}$ than in the cold season (Fig. 12). A well-mixed layer of aerosols is observed below $1.5 \mathrm{~km}$ in AMJ (Fig. 12c), consistent with the unstable lower troposphere below $1.5 \mathrm{~km}$ shown in AIRS and ERA-Interim (Fig. 13c). The WRFChem model simulates neutral (or weakly stable) layers below $1.5 \mathrm{~km}$, which may limit uplifting of aerosols from the surface, failing to create a deep well-mixed layer of aerosols (Fig. 12c). Although the dust emission at the surface is overestimated in AMJ in the 4km_D2 run, the simulated neutral or weakly stable thermal structure does not favor convective vertical mixing, resulting in the low biases of aerosols between 0.3 and $3 \mathrm{~km}$.

Similar biases of aerosol and instability in the lower troposphere are also shown in JAS (Figs. 12d and 13d). The stable boundary layer limits vertical transport of aerosols from the surface, contributing to the low bias of column-integrated AOD in JAS (Fig. 11). In JAS (Fig. 12d), aerosol extinction close to the CALIOP observation is simulated in the free atmosphere, suggesting that the low bias in AOD is not due to 

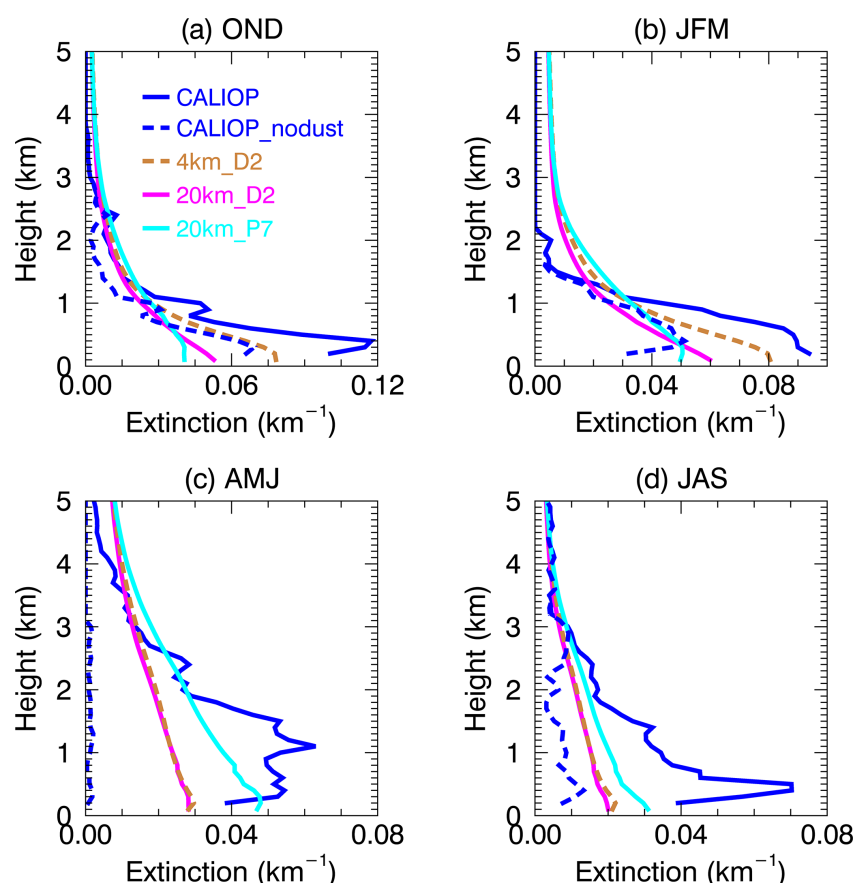

Figure 15. Vertical distribution of seasonal mean $532 \mathrm{~nm}$ aerosol extinction coefficient $\left(\mathrm{km}^{-1}\right)$ from CALIOP, CALIOP_nodust and the WRF-Chem (4km_D2, 20km_D2 and 20km_P7) simulations over the red box region in Fig. 1a in WY2013.

the halved chemical boundary conditions from MOZART-4. In the cold season, in spite of some discrepancies in the magnitude of atmospheric stability, all of the simulations capture the stable lower troposphere (Fig. 13a and b), consistent with relatively good performance of aerosol simulations in the cold season.

As biases in the model simulations are found mainly within the boundary layer, a sensitivity experiment is conducted at $20 \mathrm{~km}$ resolution using the ACM2 PBL scheme (20km_P7). Although the changes in the meteorological variables (Figs. S6-S9) and atmospheric static stability (Fig. 13) are rather small, the simulated surface $\mathrm{NO}_{3}$ and $\mathrm{NH}_{4}$ in the $20 \mathrm{~km} \_\mathrm{P} 7$ run decrease by $50 \%$ compared to the 20km_D2 run (Fig. 14c, $d$ and Table 3). Considering that more $\mathrm{NO}_{3}$ and $\mathrm{NH}_{4}$ are simulated at $4 \mathrm{~km}$ resolution than at $20 \mathrm{~km}$ resolution as shown in Sect. 4.1, the use of the ACM2 PBL scheme at $4 \mathrm{~km}$ simulation would largely resolve the high biases of $\mathrm{NO}_{3}$ and $\mathrm{NH}_{4}$ in the $4 \mathrm{~km} \_\mathrm{D} 2$ simulation. The decrease in $\mathrm{NO}_{3}$ and $\mathrm{NH}_{4}$ near the surface is because more aerosols are transported to the layers above $0.5 \mathrm{~km}$ (Fig. 15a and $b$ ), possibly resulting from different convective vertical mixing in the PBL schemes. However, $\mathrm{PM}_{2.5}$ _dust is significantly overestimated by a factor of 4 in the 20km_P7 simulation (Fig. 14h), leading to a small decrease in $\mathrm{PM}_{2.5}$ of only $8 \%$ compared with the 20km_D2 run in the cold season. In the warm season, $\mathrm{PM}_{2.5}$ _dust in the $20 \mathrm{~km} \_\mathrm{P} 7$ run is overestimated by a factor of 5 , causing an overestimation of $\mathrm{PM}_{2.5}$ and $\mathrm{PM}_{10}$ (Fig. 14a and b). Aerosol extinctions in the boundary layer above the surface increase in the warm season (Fig. 15c and d), possibly related to overestimation of dust emissions and more conducive convective vertical transport in the PBL scheme.

In summary, the WRF-Chem model captures the seasonal variations in meteorological variables (temperature, $\mathrm{RH}$, wind speed and precipitation), despite some deviations in magnitude. The low biases in aerosol optical properties of the warm season likely do not originate from hygroscopic effects, wet removal processes or dust emissions associated with the wind speed bias. The model simulates a stable environment in the warm season, which is opposite to the unstable environment observed. The simulated stable environment may be most likely responsible for low biases in the aerosol extinction above the surface $(0.3-3 \mathrm{~km})$ and the column-integrated AOD in the warm season. Switching to the ACM2 PBL scheme leads to improved vertical displacement of aerosols in the boundary layer, thus an improvement in the simulations of $\mathrm{NO}_{3}$ and $\mathrm{NH}_{4}$ in the cold season. However, dust emissions are significantly overestimated with the ACM2 PBL scheme, which contributes partly to the better simulation of aerosol extinction in the boundary layer and AOD in the column. These results highlight that improving the simulation of boundary layer structure and processes is critical for capturing the vertical profiles of aerosol extinction.

\subsubsection{Results in rural areas}

In general, low values of PM concentration are observed in the rural areas, Pinnacles and Kaiser (Figs. 16 and 17). The rural areas share some similar model performance to the urban areas, such as the overestimation of $\mathrm{NO}_{3}$, reasonable simulation of EC, good representation of $\mathrm{SO}_{4}$ in the cold season and underestimation of $\mathrm{SO}_{4}$ in the warm season. However, the results are not sensitive to model resolution. It suggests that high resolution is particularly important for heavily polluted areas due to the inhomogeneity of emission sources, but less important for relatively lightly polluted areas.

In late July and early August, MODIS (Moderate Resolution Imaging Spectroradiometer) fire data (not shown) showed active wild fires close to Kaiser, which resulted in a high local concentration of aerosols (Fig. 17). Our model simulations with monthly-varying fire emissions fail to reproduce these fire events. Previous studies (e.g., Grell et al., 2011; Wu et al., 2011a; Archer-Nicholls et al., 2015) demonstrated that the WRF-Chem model can capture aerosol distributions from wild fires based on fire locations from satellite observations. Campbell et al. (2016) further described the difficulties in constraining total aerosol mass from operational satellite fire observations and the time needed by the model for diffusion within the near-surface layers to render both reasonable AOD and vertical profiles of aerosol extinction. For operational application of the WRF- 

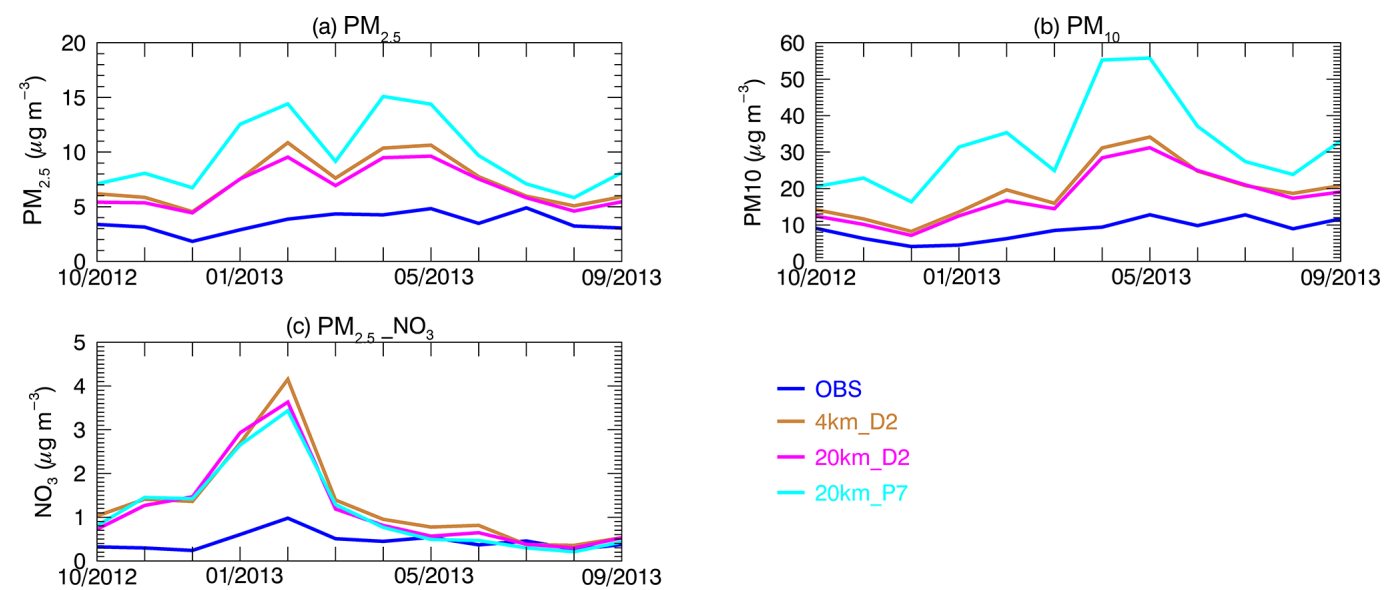

$$
\begin{aligned}
& \text { - OBS } \\
& -4 \mathrm{~km} \_\mathrm{D} 2 \\
& -20 \mathrm{~km} \_\mathrm{D} 2 \\
& -20 \mathrm{~km} \_\mathrm{P} 7
\end{aligned}
$$
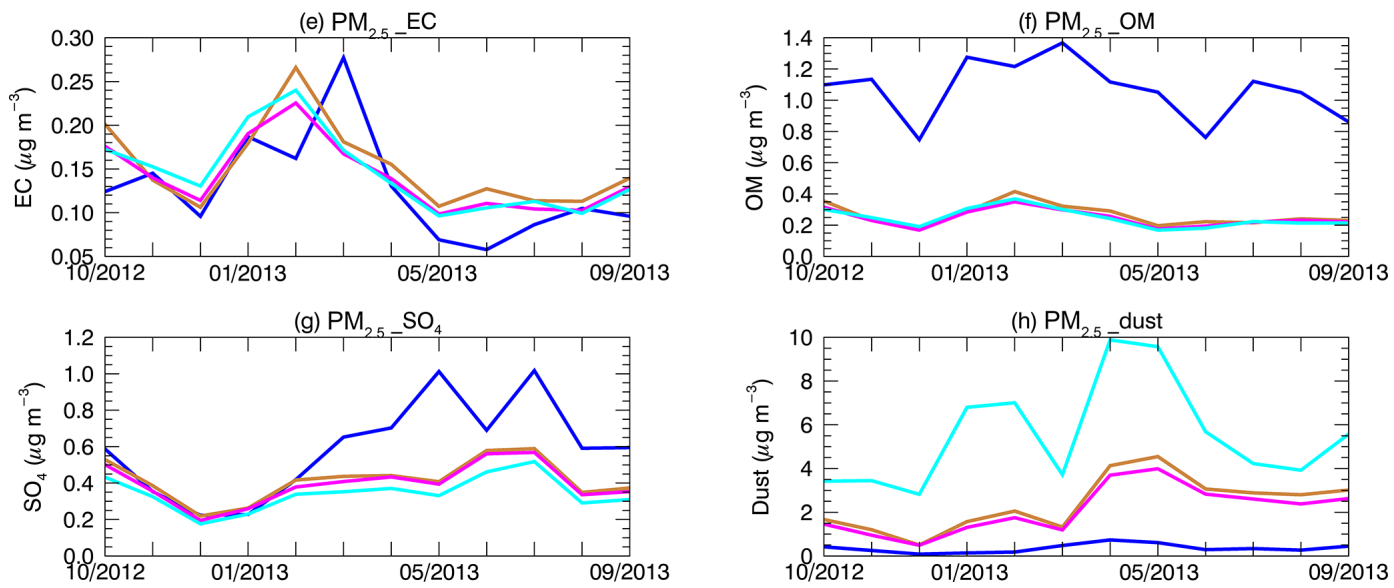

Figure 16. Aerosol mass $\left(\mu \mathrm{g} \mathrm{m}^{-3}\right)$ for different species from IMPROVE (OBS), the 4km_D2, 20km_D2 and $20 \mathrm{~km} \_$P7 simulations at Pinnacles, CA.

Chem model in MAIA retrievals, the observations of daily fire events need to be more appropriately considered.

\section{Summary}

The WRF-Chem (Weather Research and Forecasting model with Chemistry) model is employed to simulate the seasonal variability in aerosols in WY2013 (water year 2013) in the San Joaquin Valley (SJV). Model simulations are evaluated using satellite and in-situ observations. In general, the model simulations conducted at $4 \mathrm{~km}$ resolution reproduce the spatial and temporal variations in regional aerosols in the cold season, when aerosols are mainly contributed to by anthropogenic emissions in the SJV. The magnitude of simulated aerosols in the cold season however, especially in relatively dense urban areas, is sensitive to model horizontal resolution. The $4 \mathrm{~km}$ simulation has comparable magnitude to available observations, while the $20 \mathrm{~km}$ simulation underestimates aerosols. Differences in aerosol simulation fidelity as a function of variable resolutions are mainly due to the difference in aerosol emissions and simulated precipitation. Emissions at a higher resolution can better resolve the inhomogeneity of anthropogenic emissions in the SJV than at lower resolution. The sensitivity to horizontal resolution is small in rural areas and during the warm season, where and when the relative contribution of anthropogenic emissions is small.

Previous studies in the SJV were mainly focused on $\mathrm{PM}_{2.5}$ (particulate matter with a diameter $\leq 2.5 \mu \mathrm{m}$ ) and during the cold season (e.g. Chow et al., 2006; Herner et al., 2006; Pun et al., 2009; Ying and Kleeman, 2009; Zhang et al., 2010; Chen et al., 2014; Hasheminassab et al., 2014; Kelly et al., 2014; Baker et al., 2015; Brown et al., 2016). CALIOP (Cloud-Aerosol Lidar with Orthogonal Polarization) and IMPROVE (Interagency Monitoring of Protected Visual Environments) observations show that dust is a primary contributor to the aerosols in the SJV, especially in the warm season. Dust contributes $24.6 \%$ to $\mathrm{PM}_{2.5}$ and more than $75.8 \%$ to $\mathrm{PM}_{10}$ in the warm season. For all seasons, the major component of aerosol extinction in the boundary layer is dust, as observed by CALIOP, consistent with Kassianov et al. (2012). For a complete understanding of aerosol impacts on air quality, weather and climate, the full spectrum of aerosols should be considered during all seasons. 

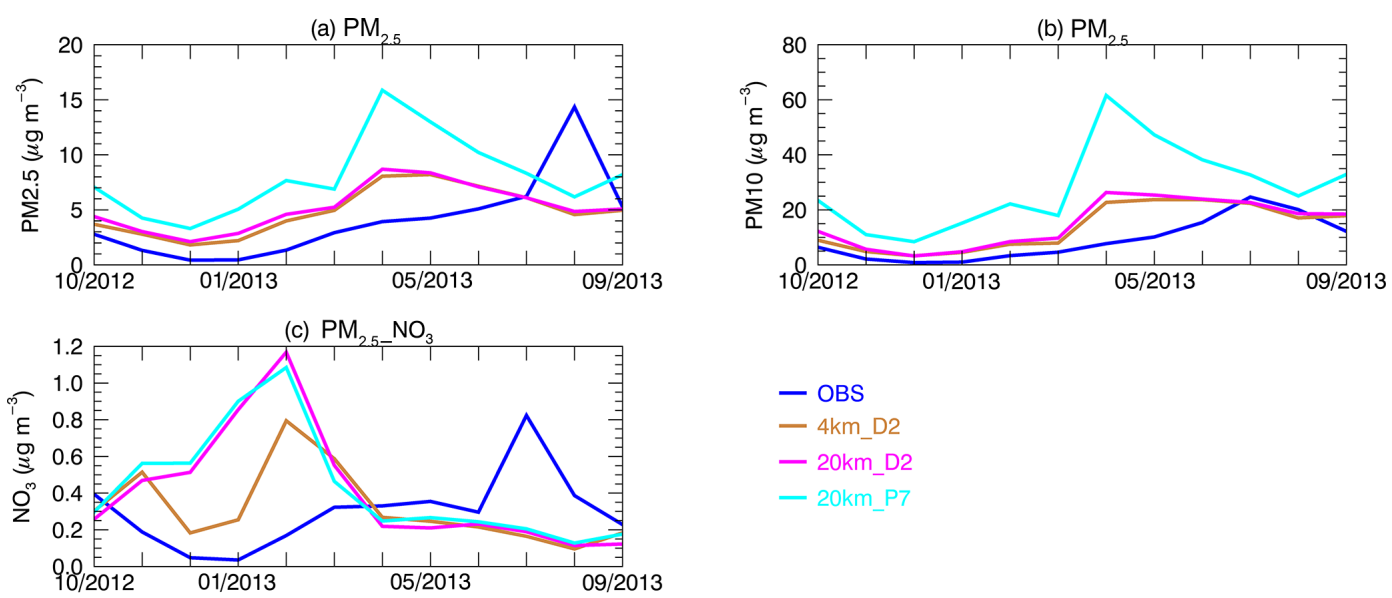

$$
\begin{aligned}
& \text { - OBS } \\
& -4 \mathrm{~km} \_D 2 \\
& -20 \mathrm{~km} \_\mathrm{D} 2 \\
& -20 \mathrm{~km} \_\mathrm{P} 7
\end{aligned}
$$
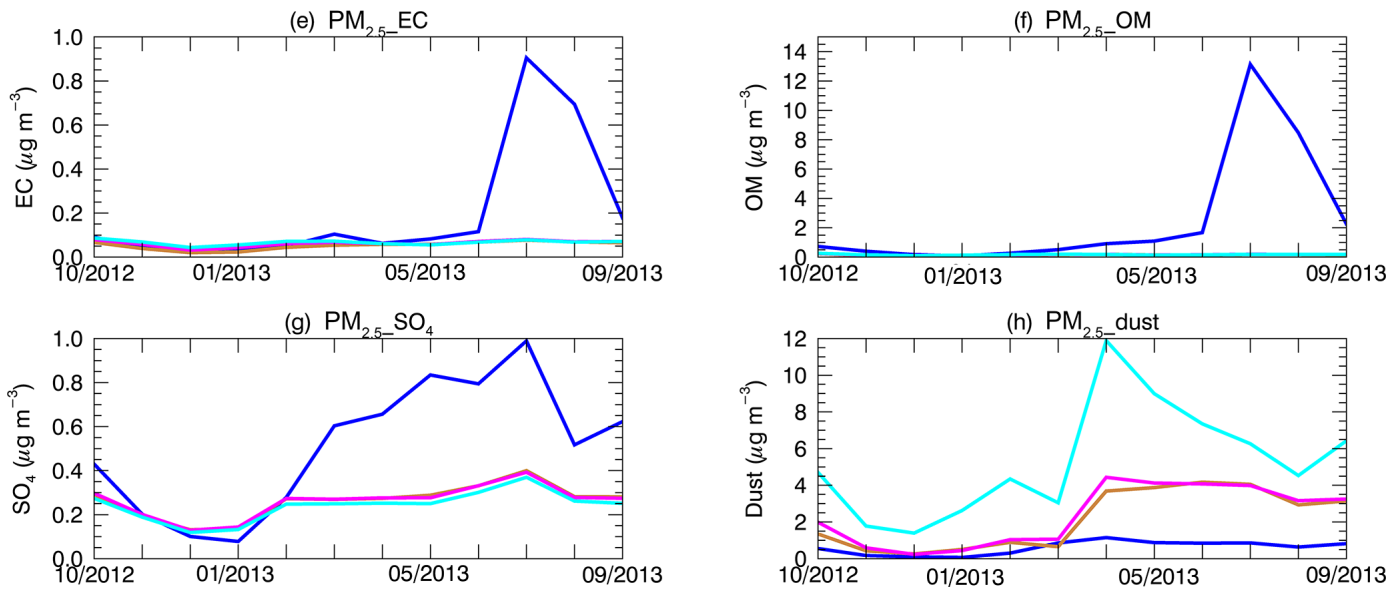

Figure 17. Aerosol mass $\left(\mu \mathrm{g} \mathrm{m}^{-3}\right.$ ) for different species from IMPROVE (OBS), the 4km_D2, 20km_D2 and $20 \mathrm{~km} \_P 7$ simulations at Kaiser, CA.

All the model simulations conducted fail to capture aerosol vertical distribution and variability in the SJV warm season, largely due to the misrepresentation of dust emissions, static stability and vertical mixing in the boundary layer. The GOCART (Goddard Global Ozone Chemistry Aerosol Radiation and Transport) dust emission scheme significantly underestimates dust due to the non-active source function, $S$, for potential wind erosion used in this study, while the DUSTRAN (DUST TRANsport model) scheme may overestimate dust emission in the SJV. Along with the bias in dust emissions, our simulations produce a relatively stable boundary layer in the warm season, in contrast with observations suggesting a more unstable environment, leading to a weak vertical mixing of aerosols in the boundary layer. Improved dust emission and better simulations of the boundary layer properties are needed for accurate simulation of aerosols in the SJV warm season.

Other biases are also identified in the model simulations. $\mathrm{NO}_{3}$ and $\mathrm{NH}_{4}$ in the cold season are overestimated in the model, but the results are sensitive to the choice of the planetary boundary layer scheme. The secondary organic aerosol processes contribute to the underestimation of organic mat- ter in this study. The underestimation of sulfate in the warm season may be caused by the misrepresentation of emissions and the chemical boundary conditions related to marine intrusions. Aerosols from wild fires are not captured in the simulations with monthly-updated fire data. Further investigations are needed to improve model simulations in the SJV for both scientific and operational applications.

Data availability. The AERONET observation is available through the following link: https://aeronet.gsfc.nasa.gov/. The MISR data are available through the following link: https://wwwmisr.jpl.nasa.gov/. The IMPROVE and EPA data are available through the following link: http://views.cira.colostate.edu/fed/ DataWizard/. The CALIPSO data are available through the following link: https://eosweb.larc.nasa.gov/project/calipso/calipso_table. The AIRS data are available through the following link: https://doi.org/10.5067/AQUA/AIRS/DATA324. The CIMIS data are available through the following link: http://wwwcimis.water.ca.gov/. The CPC data are available through the following link:

https://www.esrl.noaa.gov/psd/data/gridded/data.unified.. 
The ERA-Interim data are available through the following link: https://rda.ucar.edu//\#!lfd?nb=y\&b=proj\&v=ECMWF.

\section{The Supplement related to this article is available online at https://doi.org/10.5194/acp-17-7291-2017-supplement.}

Competing interests. The authors declare that they have no conflict of interest.

Acknowledgements. This study was carried out at the Jet Propulsion Laboratory, California Institute of Technology, under a contract with the National Aeronautics and Space Administration. The authors thank the funding support from the NASA ACMAP program and JPL PDF program. This work is partially sponsored by the California Energy Commission under grant \#EPC-14-064. The author JRC acknowledges the support of the NASA ACCDAM program and its manager Hal Maring. The authors thank the four anonymous reviewers for their helpful comments.

Edited by: Xiaohong Liu

Reviewed by: four anonymous referees

\section{References}

AERONET (AErosol RObotic NETwork): AERONET observation, NASA and PHOTONS, available at: https://aeronet.gsfc.nasa. gov/, last access: 8 June 2017.

AIRS Science Team/Joao Texeira: AIRS/Aqua L3 Monthly Support Product (AIRS-only) 1 degree $\mathrm{x} 1$ degree V006, Greenbelt, MD, USA, Goddard Earth Sciences Data and Information Services Center (GES DISC), https://doi.org/10.5067/AQUA/AIRS/DATA324, 2013.

Ångström, A.: On the atmospheric transmission of Sun radiation and on dust in the air, Geogr. Ann., 11, 156-166, 1929.

Archer-Nicholls, S., Lowe, D., Darbyshire, E., Morgan, W. T., Bela, M. M., Pereira, G., Trembath, J., Kaiser, J. W., Longo, K. M., Freitas, S. R., Coe, H., and McFiggans, G.: Characterising Brazilian biomass burning emissions using WRF-Chem with MOSAIC sectional aerosol, Geosci. Model Dev., 8, 549-577, https://doi.org/10.5194/gmd-8-549-2015, 2015.

ASDC: CALIPSO Data and Information, available at: https:// eosweb.larc.nasa.gov/project/calipso/calipso_table, last access: 8 June 2017.

Baker, K. R., Carlton, A. G., Kleindienst, T. E., Offenberg, J. H., Beaver, M. R., Gentner, D. R., Goldstein, A. H., Hayes, P. L., Jimenez, J. L., Gilman, J. B., de Gouw, J. A., Woody, M. C., Pye, H. O. T., Kelly, J. T., Lewandowski, M., Jaoui, M., Stevens, P. S., Brune, W. H., Lin, Y.-H., Rubitschun, C. L., and Surratt, J. D.: Gas and aerosol carbon in California: comparison of measurements and model predictions in Pasadena and Bakersfield, Atmos. Chem. Phys., 15, 5243-5258, https://doi.org/10.5194/acp15-5243-2015, 2015.

Banks, R. F. and Baldasano, J. M.: Impact of WRF model PBL schemes on air quality simulations over
Catalonia, Spain, Sci. Total Environ., 572, 98-113, https://doi.org/10.1016/j.scitotenv.2016.07.167, 2016.

Banks, R. F., Tiana-Alsina, J., Baldasano, J. M., Rocadenbosch, F., Papayannis, A., Solomos, S., and Tzanis, C. G.: Sensitivity of boundary-layer variables to PBL schemes in the WRF model based on surface meteorological observations, lidar, and radiosondes during the HygrA-CD campaign, Atmos. Res., 176, 185-201, 2016.

Barnard, J. C., Fast, J. D., Paredes-Miranda, G., Arnott, W. P., and Laskin, A.: Technical Note: Evaluation of the WRF-Chem "Aerosol Chemical to Aerosol Optical Properties" Module using data from the MILAGRO campaign, Atmos. Chem. Phys., 10, 7325-7340, https://doi.org/10.5194/acp-10-7325-2010, 2010.

Brown, S. G., Hyslop, N. P., Roberts, P. T., McCarthy, M. C., and Lurmann, F. W.: Wintertime vertical variations in particulate matter (PM) and precursor concentrations in the San Joaquin Valley during the California Regional Coarse PM/Fine PM Air Quality Study, J. Air Waste Ma., 56, 1267-1277, 2006.

Campbell, J. R., Tackett, J. L., Reid, J. S., Zhang, J., Curtis, C. A., Hyer, E. J., Sessions, W. R., Westphal, D. L., Prospero, J. M., Welton, E. J., Omar, A. H., Vaughan, M. A., and Winker, D. M.: Evaluating nighttime CALIOP $0.532 \mu \mathrm{m}$ aerosol optical depth and extinction coefficient retrievals, Atmos. Meas. Tech., 5, 2143-2160, https://doi.org/10.5194/amt-5-2143-2012, 2012.

Campbell, J. R., Ge, C., Wang, J., Welton, E. J., Bucholtz, A., Hyer, E. J., Reid, E. A., Chew, B. N., Liew, S.-C., Salinas, S. V., Lolli, S., Kaku, K. C., Lynch, P., Mahmud, M., Mohamad, M., and Holben, B. N.: Applying Advanced Ground-Based Remote Sensing in the Southeast Asian Maritime Continent to Characterize Regional Proficiencies in Smoke Transport Modeling, J. Appl. Meteorol. Clim., 55, 3-22, https://doi.org/10.1175/JAMC-D-150083.1, 2016.

Chapman, E. G., Gustafson Jr., W. I., Easter, R. C., Barnard, J. C., Ghan, S. J., Pekour, M. S., and Fast, J. D.: Coupling aerosol-cloud-radiative processes in the WRF-Chem model: Investigating the radiative impact of elevated point sources, Atmos. Chem. Phys., 9, 945-964, https://doi.org/10.5194/acp-9945-2009, 2009.

Chen, D., Xie, X., Zhou, Y., Lang, J., Xu, T., Yang, N., Zhao, Y., and Liu, X.: Performance Evaluation of the WRF-Chem Model with Different Physical Parameterization Schemes during an Extremely High $\mathrm{PM}_{2.5}$ Pollution Episode in Beijing, Aerosol Air Qual. Res., 17, 262-277, https://doi.org/10.4209/aaqr.2015.10.0610, 2017.

Chen, J., Lu, J., Avise, J. C., DaMassa, J. A., Kleeman, M. J., and Kaduwela, A. P.: Seasonal modeling of $\mathrm{PM}_{2.5}$ in California's San Joaquin Valley, Atmos. Environ., 92, 182-190, 2014.

Chew, B. N., Campbell, J. R., Reid, J. S., Giles, D. M., Welton, E. J., Salinas, S. V., and Liew, S. C.: Tropical cirrus cloud contamination in sun photometer data, Atmos. Environ., 45, 6724-6731, https://doi.org/10.1016/j.atmosenv.2011.08.017, 2011.

Chow, J. C., Chen, L. W. A., Watson, J. G., Lowenthal, D. H., Magliano, K. A., Turkiewicz, K., and Lehrman, D. E.: $\mathrm{PM}_{2.5}$ chemical composition and spatiotemporal variability during the California regional $\mathrm{PM}_{10} / \mathrm{PM}_{2.5}$ air quality study (CRPAQS), J. Geophys. Res., 111, D10S04, https://doi.org/10.1029/2005JD006457, 2006.

CIMIS: http://wwwcimis.water.ca.gov/Default.aspx, last access: 8 June 2017. 
CPC data, NOAA/OAR/ESRL PSD, Boulder, CO, USA, available at: https://www.esrl.noaa.gov/psd/data/gridded/data.unified. daily.conus.html, last access: 8 June 2017.

Cuchiara, G. C., Li, X., Carvalho, J., and Rappenglück, B.: Intercomparison of planetary boundary layer parameterization and its impacts on surface ozone concentration in the WRF/Chem model for a case study in Houston/Texas, Atmos. Environ., 96, 175185. https://doi.org/10.1016/j.atmosenv.2014.07.013, 2014.

Dee, D. P., Uppala, S. M., Simmons, A. J., Berrisford, P., Poli, P, Kobayashi, S., Andrae, U., Balmaseda, M. A., Balsamo, G., Bauer, P., Bechtold, P., Beljaars, A. C. M., van de Berg, L., Bidlot, J., Bormann, N., Delsol, C., Dragani, R., Fuentes, M., Geer, A. J., Haimberger, L., Healy, S. B., Hersbach, H., Hólm, E. V., Isaksen, L., Kallberg, P., Köhler, M., Matricardi, M., McNally, A. P., Monge-Sanz, B. M., Morcrette, J.-J., Park, B.-K., Peubey, C., de Rosnay, P., Tavolato, C., Thépaut, J.-N., and Vitart, F.: The ERA-Interim reanalysis: configuration and performance of the data assimilation system, Q. J. Roy. Meteor. Soc., 137, 553-597, 2011.

Diner, D. J., Beckert, J. C., Reilly, T. H., Bruegge, C. J., Conel, J. E., Kahn, R. A., Martonchik, J. V., Ackerman, T. P., Davies, R., Gerstl, S. A. W., Gordon, H. R., Muller, J. P., Myneni, R. B., Sellers, P. J., Pinty, B., and Verstraete, M. M.: Multi-angle Imaging SpectroRadiometer (MISR) Instrument Description and Experiment Overview, IEEE T. Geosci. Remote, 36, 1072-1087, 1998.

Divakarla, M. G., Barnet, C. D., Goldberg, M. D., McMillin, L. M., Maddy, E., Wolf, W., Zhou, L., and Liu, X.: Validation of Atmospheric Infrared Sounder temperature and water vapor retrievals with matched radiosonde measurements and forecasts, J. Geophys. Res., 111, D09S15, https://doi.org/10.1029/2005JD006116, 2006.

Eck, T. F., Holben, B. N., Reid, J. S., Dubovik, O., Smirnov, A., O'Neill, N. T., Slutsker, I., and Kinn, S.: Wavelength dependence of the optical depth of biomass burning urban, and desert dust aerosols, J. Geophys. Res., 104, 31333-31349, 1999.

Emmons, L. K., Walters, S., Hess, P. G., Lamarque, J.-F., Pfister, G. G., Fillmore, D., Granier, C., Guenther, A., Kinnison, D., Laepple, T., Orlando, J., Tie, X., Tyndall, G., Wiedinmyer, C., Baughcum, S. L., and Kloster, S.: Description and evaluation of the Model for Ozone and Related chemical Tracers, version 4 (MOZART-4), Geosci. Model Dev., 3, 43-67, https://doi.org/10.5194/gmd-3-43-2010, 2010.

Fast, J. D., Gustafson Jr., W. I., Easter, R. C., Zaveri, R. A., Barnard, J. C., Chapman, E. G., Grell, G. A., and Peckham, S. E.: Evolution of ozone, particulates, and aerosol direct radiative forcing in the vicinity of Houston using a fully coupled meteorology-chemistry-aerosol model, J. Geophys. Res., 111, D21305, https://doi.org/10.1029/2005JD006721, 2006.

Fast, J. D., Gustafson Jr., W. I., Berg, L. K., Shaw, W. J., Pekour, M., Shrivastava, M., Barnard, J. C., Ferrare, R. A., Hostetler, C. A., Hair, J. A., Erickson, M., Jobson, B. T., Flowers, B., Dubey, M. K., Springston, S., Pierce, R. B., Dolislager, L., Pederson, J., and Zaveri, R. A.: Transport and mixing patterns over Central California during the carbonaceous aerosol and radiative effects study (CARES), Atmos. Chem. Phys., 12, 1759-1783, https://doi.org/10.5194/acp-12-1759-2012, 2012.

Fast, J. D., Allan, J., Bahreini, R., Craven, J., Emmons, L., Ferrare, R., Hayes, P. L., Hodzic, A., Holloway, J., Hostetler, C., Jimenez, J. L., Jonsson, H., Liu, S., Liu, Y., Metcalf, A., Middlebrook, A.,
Nowak, J., Pekour, M., Perring, A., Russell, L., Sedlacek, A., Seinfeld, J., Setyan, A., Shilling, J., Shrivastava, M., Springston, S., Song, C., Subramanian, R., Taylor, J. W., Vinoj, V., Yang, Q., Zaveri, R. A., and Zhang, Q.: Modeling regional aerosol and aerosol precursor variability over California and its sensitivity to emissions and long-range transport during the 2010 CalNex and CARES campaigns, Atmos. Chem. Phys., 14, 10013-10060, https://doi.org/10.5194/acp-14-10013-2014, 2014.

FED: IMPROVE and EPA data, Federal Land Manager Environmental Database (FED), available at: http://views.cira.colostate. edu/fed/DataWizard/, last access: 8 June 2017.

Feingold, G. and Morley, B.: Aerosol hygroscopic properties as measured by lidar and comparison with in situ measurements, J. Geophys. Res., 108, 4327, https://doi.org/10.1029/2002JD002842, 2003.

Flanner, M. G. and Zender, C. S.: Snowpack radiative heating: Influence on Tibetan Plateau climate, Geophys. Res. Lett., 32, L06501, https://doi.org/10.1029/2004GL022076, 2005.

Flanner, M. G. and Zender, C. S.: Linking snowpack microphysics and albedo evolution, J. Geophys. Res., 111, D12208, https://doi.org/10.1029/2005JD006834, 2006.

Fountoukis, C., Koraj, D., Denier van der Gon, H. A. C., Charalampidis, P. E., Pilinis, C., and Pandis, S. N.: Impact of grid resolution on the predicted fine PM by a regional 3-D chemical transport model, Atmos. Environ., 68, 24-32, 2013.

Freitas, S. R., Longo, K. M., Alonso, M. F., Pirre, M., Marecal, V., Grell, G., Stockler, R., Mello, R. F., and Sánchez Gácita, M.: PREP-CHEM-SRC - 1.0: a preprocessor of trace gas and aerosol emission fields for regional and global atmospheric chemistry models, Geosci. Model Dev., 4, 419-433, https://doi.org/10.5194/gmd-4-419-2011, 2011.

Gao, Y., Liu, X., Zhao, C., and Zhang, M.: Emission controls versus meteorological conditions in determining aerosol concentrations in Beijing during the 2008 Olympic Games, Atmos. Chem. Phys., 11, 12437-12451, https://doi.org/10.5194/acp-11-124372011, 2011.

Ghan, S., Laulainen, N., Easter, R., Wagener, R., Nemesure, S., Chapman, E., Zhang, Y., and Leung, R.: Evaluation of aerosol direct radiative forcing in MIRAGE, J. Geophys. Res., 106, 52955316, https://doi.org/10.1029/2000JD900502, 2001.

Ginoux, P., Chin, M., Tegen, I., Prospero, J. M., Holben, B., Dubovik, O., and Lin, S.: Sources and distributions of dust aerosols simulated with the GOCART model, J. Geophys. Res., 106, 20225-20273, 2001.

Gong, S. L.: A parameterization of sea-salt aerosol source function for sub- and super-micron particles, Global Biogeochem. Cy., 17, 1097, https://doi.org/10.1029/2003GB002079, 2003.

Grell, G. and Devenyi, D.: A generalized approach to parameterizing convection combining ensemble and data assimilation techniques, Geophys. Res. Lett., 29, 38-1-38-4, https://doi.org/10.1029/2002GL015311, 2002.

Grell, G., Peckham, S., Schmitz, R., McKeen, S. A., Frost, G., Skamarock, W. C., and Eder, B.: Fully coupled "online" chemistry within the WRF model, Atmos. Environ., 39, 6957-6975, 2005.

Grell, G., Freitas, S. R., Stuefer, M., and Fast, J.: Inclusion of biomass burning in WRF-Chem: impact of wildfires on weather forecasts, Atmos. Chem. Phys., 11, 5289-5303, https://doi.org/10.5194/acp-11-5289-2011, 2011. 
Guenther, A., Karl, T., Harley, P., Wiedinmyer, C., Palmer, P. I., and Geron, C.: Estimates of global terrestrial isoprene emissions using MEGAN (Model of Emissions of Gases and Aerosols from Nature), Atmos. Chem. Phys., 6, 3181-3210, https://doi.org/10.5194/acp-6-3181-2006, 2006.

Hand, J., Copeland, S. A., Day, D. E., Dillner, A. M., Indresand, H., Malm, W. C., McDade, C. E., Moore Jr., C. T., Pitchford, M. L., Schichtel, B. A., and Watson, J. G.: Spatial and seasonal patterns and temporal variability of haze and its constituents in the United States: Report V, available at: http://vista.cira.colostate.edu/Improve/spatial-andseasonal-patterns-and-temporal-variability-of-haze, last access: 8 June 2017, 2011.

Hasheminassab, S., Daher, N., Saffari, A., Wang, D., Ostro, B. D., and Sioutas, C.: Spatial and temporal variability of sources of ambient fine particulate matter $\left(\mathrm{PM}_{2.5}\right)$ in California, Atmos. Chem. Phys., 14, 12085-12097, https://doi.org/10.5194/acp-1412085-2014, 2014.

Herner, J. D., Ying, Q., Aw, J., Gao, O., Chang, D. P. Y., and Kleeman, M.: Dominant mechanisms that shape the airborne particle size and composition in central California, Aerosol Sci. Technol., 40, 827-844, 2006.

Holben, B. N., Eck, T. F., Slutsker, I., Tanré, D., Buis, J. P., Setzer, A., Vermote, E., Reagan, J. A., Kaufman, Y. J., Nakajima, T., Lavenu, F., Jankowiak, I., and Smirnov, A.: AERONET - A Federated Instrument Network and Data Archive for Aerosol Characterization, Remote Sens. Environ., 66, 1-16, 1998.

Holben, B. N., Tanr, D., Smirnov, A., Eck, T. F., Slutsker, I., Abuhassan, N., Newcomb, W. W., Schafer, J. S., Chatenet, B., Lavenu, F., Kaufman, Y. J., Castle, J. V., Setzer, A., Markham, B., Clark, D., Frouin, R., Halthore, R., Karneli, A., O’Neill, N. T., Pietras, C., Pinker, R. T., Voss, K., and Zibordi, G.: An emerging ground-based aerosol climatology: Aerosol optical depth from AERONET, J. Geophys. Res., 106, 12067-12097, 2001.

Hong, S., Noh, Y., and Dudhia, J.: A new vertical diffusion package with an explicit treatment of entrainment processes, Mon. Weather Rev., 134, 2318-2341, 2006.

$\mathrm{Hu}$, X. M., Nielsen-Gammon, J.W., and Zhang, F.: Evaluation of three planetary boundary layer schemes in the WRF model, J. Appl. Meteorol. Clim., 49, 1831-1844, https://doi.org/10.1175/2010JAMC2432.1, 2010.

Hu, Z., Zhao, C., Huang, J., Leung, L. R., Qian, Y., Yu, H., Huang, L., and Kalashnikova, O. V.: Trans-Pacific transport and evolution of aerosols: evaluation of quasi-global WRF-Chem simulation with multiple observations, Geosci. Model Dev., 9, 17251746, https://doi.org/10.5194/gmd-9-1725-2016, 2016.

Iacono, M. J., Delamere, J. S., Mlawer, E. J., Shephard, M. W., Clough, S. A., and Collins, W. D.: Radiative forcing by long-lived greenhouse gases: calculations with the AER radiative transfer models, J. Geophys. Res., 113, D13103, https://doi.org/10.1029/2008JD009944, 2008.

Jaeglé, L., Quinn, P. K., Bates, T. S., Alexander, B., and Lin, J.-T.: Global distribution of sea salt aerosols: new constraints from in situ and remote sensing observations, Atmos. Chem. Phys., 11, 3137-3157, https://doi.org/10.5194/acp-11-3137-2011, 2011.

JPL: MISR data, Jet Propulsion Laboratory (JPL), NASA, CA, USA, available at: https://www-misr.jpl.nasa.gov/getData/ accessData/, last access: 8 June 2017.
Kahn, R. A., Gaitley, B. J., Garay, M. J., Diner, D. J., Eck, T. F., Smirnov, A., and Holben, B. N.: Multiangle Imaging SpectroRadiometer global aerosol product assessment by comparison with the Aerosol Robotic Network, J. Geophys. Res., 115, D23209, https://doi.org/10.1029/2010JD014601, 2010.

Kassianov, E., Pekour, M., and Barnard, J.: Aerosols in central California: Unexpectedly large contribution of coarse mode to aerosol radiative forcing, Geophys. Res. Lett., 39, L20806, https://doi.org/10.1029/2012GL053469, 2012.

Kelly, J. T., Baker, K. R., Nowak, J. B., Murphy, J. G., Markovic, M. Z., VandenBoer, T. C., Ellis, R. A., Neuman, J. A., Weber, R. J., and Roberts, J. M.: Fine-scale simulation of ammonium and nitrate over the South Coast Air Basin and San Joaquin Valley of California during CalNex-2010, J. Geophys. Res.-Atmos., 119, 3600-3614, 2014.

Lawrence, D. M., Oleson, K. W., Flanner, M. G., Thornton, P. E., Swenson, S. C., Lawrence, P. J., Zeng, X., Yang, Z.-L., Levis, S., Sakaguchi, K., Bonan, G. B., and Slater, A. G.: Parameterization improvements and functional and structural advances in version 4 of the Community Land Model, J. Adv. Model. Earth Syst., 3, M03001, https://doi.org/10.1029/2011MS000045, 2011.

Misenis, C. and Zhang, Y.: An examination of sensitivity of WRF/Chem predictions to physical parameterizations, horizontal grid spacing, and nesting options, Atmos. Res., 97, 315-334, https://doi.org/10.1016/j.atmosres.2010.04.005, 2010.

Morabito, D., Wu, L., and Slobin, S.: Weather Forecasting for Ka-band Operations: Initial Study Results, The Interplanetary Network Progress Report (IPNPR), 42-206, 1-24, available at: http://ipnpr.jpl.nasa.gov/progress_report/42-206/206C. pdf, last access: 8 June 2017, 2016.

Morrison, H., Thompson, G., and Tatarskii, V.: Impact of cloud microphysics on the development of trailing stratiform precipitation in a simulated squall line: comparison of one- and two-moment schemes, Mon. Weather Rev., 137, 991-1007, 2009.

Omar, A. H., Winker, D. M., Kittaka, C., Vaughan, M. A., Liu, Z., Hu, Y., Trepte, C. R., Rogers, R. R., Ferrare, R. A., Lee, K. P., Kuehn, R. E., and Hostetler, C. A.: The CALIPSO automated aerosol classification and lidar ratio selection algorithm, J. Atmos. Ocean. Tech., 26, 1994-2014, 2009.

Pleim, J. E.: A combined local and nonlocal closure model for the atmospheric boundary layer. Part I: Model description and testing, J. Appl. Meteorol. Clim., 46, 1383-1395, 2007.

Pun, B. K., Balmori, R. T. F., and Seigneur, C.: Modeling wintertime particulate matter formation in central California, Atmos. Environ., 43, 402-409, 2009.

Qian, Y., Gustafson Jr., W. I., and Fast, J. D.: An investigation of the sub-grid variability of trace gases and aerosols for global climate modeling, Atmos. Chem. Phys., 10, 6917-6946, https://doi.org/10.5194/acp-10-6917-2010, 2010.

Randerson, J. T., van der Werf, G. R., Giglio, L., Collatz, G. J., and Kasibhatla, P. S.: Global Fire Emissions Database, Version 2 (GFEDv2.1). Data set, Oak Ridge National Laboratory Distributed Active Archive Center, Oak Ridge, Tennessee, USA, https://doi.org/10.3334/ORNLDAAC/849, 2007.

RDA: ERA-Interim data, NCAR UCAR, Boulder, CO, USA, available at: https://rda.ucar.edu/\#!lfd?nb=y\&b=proj\&v= ECMWFInterimReanalysis, last access: 8 June 2017.

Scarino, A. J., Obland, M. D., Fast, J. D., Burton, S. P., Ferrare, R. A., Hostetler, C. A., Berg, L. K., Lefer, B., Haman, 
C., Hair, J. W., Rogers, R. R., Butler, C., Cook, A. L., and Harper, D. B.: Comparison of mixed layer heights from airborne high spectral resolution lidar, ground-based measurements, and the WRF-Chem model during CalNex and CARES, Atmos. Chem. Phys., 14, 5547-5560, https://doi.org/10.5194/acp-145547-2014, 2014.

Schuster, G. L., Dubovik, O., and Holben, B. N.: Angström exponent and bimodal aerosol size distributions, J. Geophys. Res., 111, D07207, https://doi.org/10.1029/2005JD006328, 2006.

Shaw, W., Allwine, K. J., Fritz, B. G., Rutz, F. C., Rishel, J. P., and Chapman, E. G.: An evaluation of the wind erosion module in DUSTRAN, Atmos. Environ., 42, 1907-1921, 2008.

SJV APCD (San Joaquin Valley Air Pollution Control District): 2012 PM2.5 plan, available at: http://www.valleyair.org/Air Quality_Plans/PM25Plans2012.htm, last access: 8 June 2017, 2012.

Solomon, P. A., Crumpler, D., Flanagan, J. B., Jayanty, R. K. M., Rickman, E. E., and McDade C. E.: U.S. National PM 2.5 Chemical Speciation Monitoring Networks - CSN and IMPROVE: Description of Networks, J. Air Waste Ma., 64, 1410-1438, https://doi.org/10.1080/10962247.2014.956904, 2014.

Stroud, C. A., Makar, P. A., Moran, M. D., Gong, W., Gong, S., Zhang, J., Hayden, K., Mihele, C., Brook, J. R., Abbatt, J. P. D., and Slowik, J. G.: Impact of model grid spacing on regionaland urban- scale air quality predictions of organic aerosol, Atmos. Chem. Phys., 11, 3107-3118, https://doi.org/10.5194/acp11-3107-2011, 2011.

Susskind, J., Barnet, C. D., and Blaisdell, J.: Retrieval of atmospheric and surface parameters from AIRS/AMSU/HSB data under cloudy conditions, IEEE T. Geosci. Remote, 41, 390-409, https://doi.org/10.1109/TGRS.2002.808236, 2003.

Tessum, C. W., Hill, J. D., and Marshall, J. D.: Twelve-month, $12 \mathrm{~km}$ resolution North American WRF-Chem v3.4 air quality simulation: performance evaluation, Geosci. Model Dev., 8, 957973, https://doi.org/10.5194/gmd-8-957-2015, 2015.

Toth, T. D., Campbell, J. R., Reid, J. S., Tackett, J. L., Vaughan, M. A., and Zhang, J.: Lower daytime threshold sensitivities to aerosol optical thickness in CALIPSO Level 2 products, J. Geophys. Res., in review, 2017.

US EPA: Technical Support Document: Preparation of Emissions Inventories for the Version 4, 2005-based Platform, 73 pp., Office of Air Quality Planning and Standards, Air Quality Assessment Division, US Environmental Protection Agency (US EPA), available at: https://www3.epa.gov/crossstaterule/ pdfs/2005_emissions_tsd_07jul2010.pdf, 2010.

Wu, L. and Petty, G. W.: Intercomparison of Bulk Microphysics Schemes in Simulations of Polar lows, Mon. Weather Rev., 138, 2211-2228, https://doi.org/10.1175/2010MWR3122.1, 2010.

Wu, L., Su, H., and Jiang, J. H.: Regional simulations of deep convection and biomass burning over South America: 1. Model evaluations using multiple satellite data sets, J. Geophys. Res., 116, D17208, https://doi.org/10.1029/2011JD016105, 2011a.

Wu, L., Su, H., and Jiang, J. H.: Regional simulations of deep convection and biomass burning over South America: 2. Biomass burning aerosol effects on clouds and precipitation, J. Geophys. Res., 116, D17209, https://doi.org/10.1029/2011JD016106, $2011 b$.
Wu, L., Su, H., and Jiang, J. H.: Regional simulations of aerosol impacts on precipitation during the East Asian summer monsoon, J. Geophys. Res.-Atmos., 118, 6454-6467, https://doi.org/10.1002/jgrd.50527, 2013.

Wu, L., Li, J.-L. F., Pi, C.-J., Yu, J.-Y., and Chen, J.-P.: An observationally based evaluation of WRF seasonal simulations over the Central and Eastern Pacific, J. Geophys. Res.-Atmos., 120, 10664-10680, https://doi.org/10.1002/2015JD023561, 2015.

Xie, B., Fung, J. C. H., Chan, A., and Lau, A.: Evaluation of nonlocal and local planetary boundary layer schemes in the WRF model, J. Geophys. Res., 117, D12103, https://doi.org/10.1029/2011JD017080, 2012.

Ying, Q. and Kleeman, M. J.: Regional contributions to airborne particulate matter in central California during a severe pollution episode, Atmos. Environ., 43, 1218-1228, 2009.

Young, S. A. and Vaughan, M. A.: The retrieval of profiles of particulate extinction from Cloud-Aerosol Lidar Infrared Pathfinder Satellite Observations (CALIPSO) data: algorithm description, J. Atmos. Ocean. Tech., 26, 1105-1119, 2009.

Zaveri, R. A. and Peters, L. K.: A new lumped structure photochemical mechanism for large-scale applications, J. Geophys. Res., 104, 30387-30415, 1999.

Zaveri, R. A., Easter, R. C., Fast, J. D., and Peters, L. K.: Model for Simulating Aerosol Interactions and Chemistry (MOSAIC), J. Geophys. Res., 113, D13204, https://doi.org/10.1029/2007JD008782, 2008.

Zhang, Y., Liu, P., Liu, X.-H., Pun, B., Seigneur, C., Jacobson, M. Z., and Wang, W.-X.: Fine scale modeling of wintertime aerosol mass, number, and size distributions in central California, J. Geophys. Res., 115, D15207, https://doi.org/10.1029/2009jd012950, 2010.

Zhao, C., Liu, X., Leung, L. R., Johnson, B., McFarlane, S. A., Gustafson Jr., W. I., Fast, J. D., and Easter, R.: The spatial distribution of mineral dust and its shortwave radiative forcing over North Africa: modeling sensitivities to dust emissions and aerosol size treatments, Atmos. Chem. Phys., 10, 8821-8838, https://doi.org/10.5194/acp-10-8821-2010, 2010.

Zhao, C., Liu, X., Ruby Leung, L., and Hagos, S.: Radiative impact of mineral dust on monsoon precipitation variability over West Africa, Atmos. Chem. Phys., 11, 1879-1893, https://doi.org/10.5194/acp-11-1879-2011, 2011.

Zhao, C., Chen, S., Leung, L. R., Qian, Y., Kok, J. F., Zaveri, R. A., and Huang, J.: Uncertainty in modeling dust mass balance and radiative forcing from size parameterization, Atmos. Chem. Phys., 13, 10733-10753, https://doi.org/10.5194/acp-13-107332013, 2013a.

Zhao, C., Leung, L. R., Easter, R., Hand, J., and Avise, J.: Characterization of speciated aerosol direct radiative forcing over California, J. Geophys. Res., 118, 2372-2388, https://doi.org/10.1029/2012JD018364, 2013b.

Zhao, C., Hu, Z., Qian, Y., Ruby Leung, L., Huang, J., Huang, M., Jin, J., Flanner, M. G., Zhang, R., Wang, H., Yan, H., Lu, Z., and Streets, D. G.: Simulating black carbon and dust and their radiative forcing in seasonal snow: a case study over North China with field campaign measurements, Atmos. Chem. Phys., 14, 1147511491, https://doi.org/10.5194/acp-14-11475-2014, 2014. 